THE LONDON SCHOOL

OF ECONOMICS AND

POLITICAL SCIENCE

Economic History Working Papers

No: $246 / 2016$

\title{
Monetary Versus Macroprudential Policies: Causal Impacts Of Interest Rates And Credit Controls In The Era Of The UK Radcliffe Report
}

\author{
David Aikman \\ Bank of England \\ Oliver Bush \\ Bank of England and London School of Economics \\ Alan M. Taylor \\ University of California, Davis, NBER and CEPR
}




\title{
LONDON SCHOOL OF ECONOMICS AND POLITICAL SCIENCE \\ DEPARTMENT OF ECONOMIC HISTORY \\ WORKING PAPERS
}

NO. 246 - JUNE 2016

\section{Monetary Versus Macroprudential Policies: Causal Impacts Of Interest Rates And Credit Controls In The Era Of The UK Radcliffe Report}

\author{
David Aikman \\ Financial Stability Strategy and Risk, Bank of England \\ david.aikman@,bankofengland.co.uk \\ Oliver Bush \\ Bank of England and London School of Economics \\ o.bush@1se.ac.uk \\ Alan M. Taylor \\ Department of Economics and Graduate School of Management, \\ University of California, Davis; NBER; and CEPR \\ amtaylor@ucdavis.edu
}

\begin{abstract}
We have entered a world of conjoined monetary and macroprudential policies. But can they function smoothly in tandem, and with what effects? Since this policy cocktail has not been seen for decades, the empirical evidence is almost non-existent. We can only fix this shortcoming in a historical laboratory. The Radcliffe Report (1959), notoriously skeptical about the efficacy of monetary policy, embodied views which led the UK to a three-decade experiment of using credit controls alongside conventional changes in the central bank interest rate. These non-price tools are similar to policies now being considered or used by macroprudential policymakers. We describe these tools, document how they were used by the authorities, and craft a new, largely hand-collected dataset to help estimate their effects. We develop a novel identification strategy, which we term Factor-Augmented Local Projection (FALP), to investigate the subtly different impacts of both monetary and macroprudential policies. Monetary policy acted on output and inflation broadly in line with consensus views today, but credit controls had markedly different effects and acted primarily to modulate bank lending.
\end{abstract}

JEL codes: E50, G18, N14.

Keywords: Monetary policy, macroprudential policy, credit controls.

The views expressed in this paper are those of the authors and not necessarily those of the Bank of England. The authors wish to thank - without implicating — Thilo Albers, Saleem Bahaj, Michael Bordo, Forrest Capie, Matthieu Chavaz, James Cloyne, Angus Foulis, Julia Giese, Charles Goodhart, Robert Hetzel, Ethan Ilzetzki, Òscar Jordà Duncan Needham, Jonathan Pinder, Ricardo Reis, Gary Richardson, Albrecht Ritschl, Joan Rosés, Peter Sinclair, Ryland Thomas, Eugene White, and Garry Young for helpful conversations, and Casey Murphy, Consgor Osvay, and Jenny Spyridi for their excellent research assistance. We have benefited from comments of participants at presentations at the Cliometric Society Annual Conference, the American Economic Association Annual Meetings, the Federal Reserve conference on economic and financial history, the INET Young Scholars' Initiative economic history conference, the London School of Economics and the Bank of England. 
But, when all has been said on the possibility of monetary action and of its likely efficacy, our conclusion is that monetary measures cannot alone be relied upon to keep in nice balance an economy subject to major strains from both without and within. Monetary measures can help, but that is all.

- The Radcliffe Report ${ }^{1}$

\section{Introduction: Macropru in the Rear-View Mirror}

The Global Financial Crisis and its disappointing aftermath are widely viewed as a major macroeconomic policy disaster from which lessons must be learned. Yet agreement on the precise failures and, thus, the necessary lessons, has been elusive in many areas, from mortgage regulation to fiscal policy, and from global imbalances to central banking. In the latter case, the role of macroprudential policies remains fraught, with doubts about whether they should exist, if they work, and how they should be designed and used. ${ }^{2}$

Reflecting this range of skepticism, several countries have recently taken quite varied courses of action in retooling their policy regimes since 2008. For example, facing a heating up of their housing markets in 2010-12, Sweden and Norway took quite different policy actions. Sweden's Riksbank tried to battle this development using monetary policy tools only, raising the policy rate, and tipping the economy into deflation, as had been predicted by the dissident Deputy Governor Lars Svensson, who subsequently resigned. Across the border, the Norges Bank implemented some cyclical macroprudential policies to crimp credit expansion and moderate mortgage and house-price booms, without relying as much on rate rises, and they managed to avoid such an out-turn. Elsewhere, other countries display differing degrees of readiness or willingness to use time-varying macroprudential policies. The Bank of England now has both a Financial Policy Committee and a Monetary Policy Committee, and the former has already taken macroprudential policy actions under Governor Mark Carney. As Governor of the Bank of Israel, Stanley Fischer utilized macroprudential policies against perceived housing and credit boom risks, but now as

\footnotetext{
${ }^{1}$ Committee on the Working of the Monetary System (1959), paragraph 514, page 183.

${ }^{2}$ See, e.g., Cochrane (2013), Crockett (2000), Economist (2014), Kennedy (2014), Milne (2014), Tarullo (2013).
} 
Vice-Chair at the Federal Reserve his speeches lament the lack of similarly strong and unified macroprudential powers at the U.S. central bank. ${ }^{3}$ Yet as one surveys these and other tacks taken by national and international policymakers, two features of the post-crisis reaction stand out: the extent to which these policy choices have proved contentious even given their limited scope and span of operation, and the way that the debate on this policy revolution has remained largely disconnected from any empirical evidence. And of course, the two features may be linked.

This paper seeks a scientific approach that might address both of these shortcomings, by bringing a new and vastly larger array of formal empirical evidence to the table. To that end, we turn to the last great era of central bank experimentation with the same types of macroprudential instruments: the postwar decades from the 1950 s to the early 1980 when many types of credit controls were put in play. We go back and construct by hand new quantitative indicators on the application of such policies in the UK, including credit ceilings, hire purchase regulations, special deposits, and the "Corset."4

To evaluate the impacts of these policies, and to compare them with the impacts of the standard monetary policy tool of Bank Rate, we then implement a state-of-art econometric estimation of impulse-response functions (IRFs) to the two policy shocks by developing a new approach to identification that is also original to this paper, one that we shall refer to as Factor-Augmented Local Projection (FALP). Our approach unites the flexible and parsimonious local projection (LP) method of estimating IRFs (Jordà 2005) with the Romer and Romer (2004) approach of using forecasts to mitigate the selection bias arising from policymakers acting on their expectations of future macroeconomic developments. To ensure greater robustness, we also borrow from the factor augmentation approach that

\footnotetext{
3See Fischer (2014), who compares macroprudential regimes in Israel and UK with the US, and states: "It may well be that adding a financial stability mandate to the overall mandates of all financial regulatory bodies, and perhaps other changes that would give more authority to a reformed FSOC, would contribute to increasing financial and economic stability."

See also Fischer (2015): "The need for coordination across different regulators with distinct mandates creates challenges to the timely deployment of macroprudential measures in the United States. Further, the toolkit to act countercyclically in the face of building financial stability risks is limited, requires more research on its efficacy, and may need to be enhanced."

4We follow Miller (1973) in referring to these instruments as "credit controls" and use the term "credit policy" to describe these policies taken as a whole.
} 
has been employed in the VAR literature (Bernanke et al. 2005) as a means to control for other information correlated both with changes in policy and future macroeconomic developments. We subject out results to a range of robustness tests, most of which give us little reason to doubt our main results.

What do we learn from this study - about these policies in their own time, and in terms of lessons for today? In one respect, our evidence suggests that the policies from the Radcliffe era were actually a bit of a failure judged on their own terms, when we recall that the policymakers at the time viewed credit policy tools as a substitute for monetary policy. That is, in the old days the Bank of England thought that it could use credit controls to fine-tune macroeconomic outcomes in line with the government's stated objectives for output, inflation, and so on. But we find only mixed evidence for this belief. Changes in credit controls did strongly depress lending; but their effects on output (dampened) and the trade balance (improved) are somewhat less robust; and credit controls seemed to have no negative impact on consumer prices. At the same time, we find that changes to the policy rate seem to have delivered their usual impacts of conventional sign and magnitude on output and inflation, in full accord with today's consensus views and empirical evidence.

As for today, if a similar set of macroprudential tools were to operate as it did in the Radcliffe era, it might fairly be said that "it does exactly what it says on the tin." It would more strongly modulate credit creation, and yet would have weaker output and inflation impacts than conventional monetary policy. ${ }^{5}$ Since the underlying IRFs span very different outcome spaces, a major claim by proponents of macroprudential policies has now at least some evidence behind it. That is, a non-duplicating but complementary mix of monetary and macroprudential policy tools may exist which can curb the credit cycle, and so moderate financial instability risks without harming the real economy unduly, or less so than with only a pure monetary policy action like a leaning-against-the-wind rate hike.

\footnotetext{
In addition, today's macroprudential authorities typically emphasize that their tools have a direct impact on the resilience of the financial system, which is over and above any impact they may have on credit dynamics and the financial cycle. That is, by requiring banks and other intermediaries to have higher buffers of capital and liquidity when risks are judged to be elevated, the financial system will be better placed to weather an episode of out-sized losses without curtailing essential lending and other intermediation services to the real economy. See Bank of England (2009) for discussion.
} 


\section{Credit Policy in the Radcliffe Era}

The Report of the Committee on the Working of the Monetary System (1959), universally known as the Radcliffe Report, was a publication of major importance in the history of UK monetary policy. Commissioned by the Chancellor of the Exchequer, and the outcome of two years of hearings, the Report was a wide-ranging survey of the structure and operation of the UK monetary and financial system. The number of scholarly citations it received within ten years of publication - around 2000, including a paper marking its tenth anniversary by Anna Schwartz (1969) - is testament to the stir it caused in academia. ${ }^{6}$ Whether or not it led to immediate significant changes in UK policymaking, it merits a chapter in the official history of the Bank of England (Capie 2010), not least because it is an excellent guide to official thinking at the time. Ten years on, the Bank of England stated clearly that "the approach to policy has been similar to that of the Radcliffe Committee"; and arguably it was only with the arrival of the Thatcher Government in 1979 that the ideas of the Radcliffe era were finally and completely abandoned.

What was the Radcliffean approach to policymaking? First of all, don't trust monetary policy to achieve the objectives of full employment, stable prices, and external balance. The Report concluded that money was highly substitutable for other financial assets and therefore the effects of the policy rate on the demand for goods would be so small that relying on it alone to stabilise the domestic economy would "increase drastically the range of movements of rates of interest." ${ }^{8}$ Given the implications of such a policy for the volatility of gilt prices, the Committee warned that "there can be no reliance on this weapon [the policy rate] as a major short-term stabiliser of demand." 9 The view endured, and even a decade later the Bank of England still felt that "in the present state of our knowledge, it looks unlikely that we shall ever be able to rely primarily on monetary policy for short-term stabilisation of the economy and the balance of payments."10

\footnotetext{
${ }^{6}$ Citation count from a Google Scholar search.

7Bank of England (1969).

${ }^{8}$ Committee on the Working of the Monetary System (1959), paragraph 489, page 174.

${ }^{9}$ Committee on the Working of the Monetary System (1959), para 498, page 177.

${ }^{10}$ Bank of England (1969).
} 
Second, the Report cautions against "doctrinal preference" being given to one particular monetary policy tool, instead favouring a more flexible approach encompassing ratio controls on banks (and perhaps non-banks) and hire-purchase restrictions. These tools would affect the liquidity positions of lenders, thereby influencing "the state of liquidity of the whole economy," of which the supply of money was merely a part. ${ }^{11}$ Credit controls had been preferred to Bank Rate since the 1950s by the Treasury, given the impact of tighter monetary policy on interest payments on the large stock of government debt. ${ }^{12}$ In the twenty years that followed Radcliffe, credit policy tools in use included debt management, calls for special deposits (similar to remunerated reserve requirements), restrictions on the terms of hire purchase (i.e., instalment) lending, qualitative guidance over and quantitative limits on lending, and calls for supplementary special deposits (the "Corset" - similar to unremunerated reserve requirements). As explained above, these tools are of great interest for us now, since many of the policies under consideration by today's macroprudential policymakers are in many ways similar to the Radcliffe era's credit controls.

The focus of this paper is the use and effects of monetary and credit controls in the two decades after the Radcliffe Report. In light of the consensus that has since developed on the significant effects of monetary policy in normal times (Romer and Romer, 2013), we would be surprised to find that Radcliffe Committee members were right to be as skeptical as they were about monetary policy, and our results will confirm these priors. Nevertheless, even critics of the Report had painted a picture in which movements in the policy rate were offset by simultaneous increases in the money supply to prevent falls in gilt prices (Hodgman 1971). Other reasons for smaller effects also spring to mind. First, the exchange rate channel was shut down for over half this period as the Bretton Woods system was still operating. So monetary policy did not stimulate exports and rotate domestic demand towards domestically-produced goods and services. Second, monetary policy may have had less impact on bond yields than in more recent periods as market participants found it harder to make inferences about the implications of a change in the policy rate for the

\footnotetext{
${ }^{11}$ Committee on the Working of the Monetary System (1959), para 981, page 337.

${ }^{12}$ See, e.g., the exchange in 1951 between the Chancellor Gaitskell and Governor Cobbold documented on pages 309 to 393 of Fforde (1992).
} 
future path of monetary policy. ${ }^{13}$ If these hypotheses have even some truth to them, the effects of monetary policy over our period of study (the 1960s and 7os) may well be smaller than in other periods, such as has been found in the contemporary literature.

In contrast to the huge body of empirical work on the impact of monetary policy, there is almost no literature on credit controls using modern methods to which we can compare and contrast our results. But some recent examples are Elliott et al. (2013) and Zdzienicka et al. (2015) for the U.S., and Monnet (2012, 2014a) for France and Europe. Elliott et al. document the extensive use of credit policies in the U.S. from the 1920s onwards. A range of tools was used in the U.S. including loan-to-value ratios and maturity limits, margin requirements, interest rate ceilings, reserve requirements, and moral suasion to reduce lending in booms. Elliott et al.'s preliminary analysis finds that tighter credit policies lowered consumer debt, while loosening did not raise it. Building on this work, Zdzienicka et al. find that both monetary and credit policy had a dampening effect on financial conditions, but the effect of credit policy was more immediate and shorter-lived. ${ }^{14}$ In France, Monnet shows that reserve and liquidity requirements, and credit ceilings were frequently used. He also documents the use of non-standard monetary measures such as individual bank discount ceilings. Monnet finds that a tightening in non-price monetary and credit policy leads to a fall in lending, output, and prices, and an improvement in the current account balance. Monnet (2014b) describes the widespread use of similar credit policies in other European countries, with the notable exception of Germany. However, none of these papers simultaneously examines the impacts of monetary and credit policies in a unified empirical framework, as we do - and this matters since, in reality, both policies may be operative (but imperfectly correlated), as we will show; and, as an empirical design, ignoring the simultaneous effects of monetary policy when gauging the impact of credit policy (or vice versa) would raise concerns about potential omitted-variable bias.

The key contributions of this paper are: to document the use of credit policies in the UK;

\footnotetext{
${ }^{13}$ Ellis et al. (2014) find that bond yields reacted more to policy shocks after inflation targeting was introduced in the UK

${ }^{14}$ Romer and Romer (1993) find that US monetary and credit policy both depress industrial production and increase credit spreads, but monetary policy acts relatively more on IP.
} 
to assemble a new monthly UK macroeconomic dataset covering the 1960s, 70s and early 8os; to introduce a novel identification strategy which we call Factor-Augmented Local Projection (FALP); and jointly to estimate the causal effects of UK monetary and credit policies over this period. The rest of the paper is structured as follows.

In Section 3, we document the various credit policies that were used in the UK and show how, as envisaged by the Radcliffe Report, they often varied to support changes in the policy rate, although the two were never perfectly in sync. In the remainder of the paper, we investigate the distinct effects of changes in monetary and credit policy. Section 4 describes our approach to identification which relies on forecasts and factors to summarise the data available to policymakers and local projections to trace out impulse response functions (IRFs). There we also discuss the data used, in particular our new forecast and monthly macroeconomic datasets.

Section 5 presents our estimates of the causal effects of changes in monetary and credit controls on measures of lending, output, inflation, and the external balance. As three of the five objectives of monetary policy according to the Radcliffe Report were maintaining price stability, keeping economic growth steady, and strengthening the external position, our results cast light directly on the contribution monetary and credit policies could have made to meeting the objectives as laid out by the Radcliffe Committee. ${ }^{15}$ Our results suggest that increases in the policy rate had negative effects on manufacturing output and consumer prices, and positive effects on the trade balance. ${ }^{16}$ The effects of credit policies are harder to discern, but we find robust evidence of a significant negative impact on bank lending and some weaker results consistent with a depressing effect on output via a supply or working capital channel.

In Section 6 we use our estimated IRFs to decompose the shocks driving lending, output, and inflation in the 1960s and 7os. We find that monetary and credit policies were important drivers of credit and output cycles and played an important role in the pickup in inflation in

\footnotetext{
${ }^{15}$ Committee on the Working of the Monetary System (1959), paragraph 69, page 22.

${ }^{16}$ For much of the sample period, under Bretton Woods, exchange rates were fixed, meaning that the expenditure switching channel was not operative; hence, the impact on the trade balance is not so surprising.
} 
the 1970s. In Section 7 we investigate the effect of monetary and credit policies on variables which may be important indicators of systemic risk. While credit policies may be less well-suited to achieving monetary stability than monetary policy, our evidence suggests they may be better-suited to achieving financial stability. Section 8 concludes and raises further related questions of interest.

\section{Description and Use of Credit Policy Tools}

In this section we will lay out the details of the four main cyclical credit controls used over this period:

- Special deposits;

- The supplementary special deposits Scheme (the "Corset");

- Credit ceilings; and

- Hire-purchase restrictions (minimum down-payment and maximum repayment terms).

Table 1 provides a summary of these tools, including the authority responsible for setting each tool, the institutions to which they applied, and their usage over the period we examine. Banks over this period were also subject to various other liquidity requirements, including a uniform minimum liquidity ratio and cash ratio (Bank of England, 1962a). However, the calibration of these requirements was largely unchanged over the period, and so they have been excluded from this analysis. ${ }^{17}$

\subsection{Description of credit policy tools}

Special deposits Special deposits were akin to a remunerated reserve requirement. Banks were requested to place varying amounts of deposits at the Bank of England, in an amount

\footnotetext{
${ }^{17}$ From 1946, the clearing banks agreed to maintain a minimum reserve-to-deposit ratio of $8 \%$. From 1951, the clearing banks agreed to maintain a liquid asset ratio of reserves, call money and Treasury and commercial bills of $28 \%-32 \%$ of their deposit liabilities; from 1957, this agreement was made more precise when the liquid asset ratio was set at a minimum of 30\%; in 1968, this was reduced to $28 \%$ (Capie and Webber, 1985).
} 
Table 1: A summary of credit policy tools used by the UK authorities

\begin{tabular}{|c|c|c|c|c|}
\hline $\begin{array}{l}\text { Policy } \\
\text { instrument }\end{array}$ & Description & $\begin{array}{l}\text { Responsible } \\
\text { authority }\end{array}$ & Scope & Usage \\
\hline Special Deposits & $\begin{array}{l}\text { Requirements to place interest- } \\
\text { bearing deposits at the Bank of } \\
\text { England }\end{array}$ & Bank of England & $\begin{array}{l}\text { London and Scottish } \\
\text { clearing banks / retail } \\
\text { banks after 1971 }\end{array}$ & $\begin{array}{l}\text { Scheme first used in } \\
\text { April 1960, and used } \\
\text { frequently throughout } \\
\text { 1960s and 1970s }\end{array}$ \\
\hline $\begin{array}{l}\text { Supplementary } \\
\text { Special Deposits } \\
\text { (The "Corset") }\end{array}$ & $\begin{array}{l}\text { Requirements to place non- } \\
\text { interest bearing deposits at the } \\
\text { Bank of England if interest- } \\
\text { bearing eligible liabilities grew } \\
\text { faster than a specified rate }\end{array}$ & Bank of England & $\begin{array}{l}\text { All listed banks and } \\
\text { deposit-taking finance } \\
\text { houses; small institu- } \\
\text { tions and Northern Irish } \\
\text { banks were exempt }\end{array}$ & $\begin{array}{l}\text { Scheme activated on } \\
\text { three occasions: Decem- } \\
\text { ber 1973; November } \\
\text { 1976; June 1978 }\end{array}$ \\
\hline Credit Ceilings & $\begin{array}{l}\text { Short-term qualitative and quan- } \\
\text { titative ceilings on the level of } \\
\text { credit extended to the private } \\
\text { sector and overseas (excluding } \\
\text { export finance) }\end{array}$ & Bank of England & $\begin{array}{l}\text { London and Scottish } \\
\text { clearing banks and } \\
\text { other listed banks; } \\
\text { restraint letters also } \\
\text { sent to finance houses, } \\
\text { acceptance } \\
\text { and discount mouses } \\
\text { participants }\end{array}$ & $\begin{array}{l}\text { Scheme used on vari- } \\
\text { ous occasions in 1950s, } \\
\text { 1960 and 1970s }\end{array}$ \\
\hline $\begin{array}{l}\text { Hire-Purchase } \\
\text { Restrictions }\end{array}$ & $\begin{array}{l}\text { Restrictions on terms of hire } \\
\text { purchase (instalment) lending } \\
\text { for different categories of con- } \\
\text { sumer goods, including mini- } \\
\text { mum down-payments and maxi- } \\
\text { mum repayment periods }\end{array}$ & $\begin{array}{l}\text { Board of Trade (UK } \\
\text { government) }\end{array}$ & Market-wide & $\begin{array}{l}\text { Used throughout the } \\
\text { 1950s, 1960s and 1970s, } \\
\text { until their removal in } \\
\text { 1982 }\end{array}$ \\
\hline
\end{tabular}

proportional to their deposit bases, at an interest rate close to the Treasury bill rate. ${ }^{18}$ Banks were given about 60 days on average to meet requests for additional deposits, and about 20 days to comply when policy was loosened. The scheme applied to the London and Scottish clearing banks only; at the time, these institutions held roughly $85 \%$ of sterling deposits in the UK economy.

The tool was intended to influence banks' ability to expand credit by acting on their minimum liquidity ratios: special deposits did not count as liquid assets for the purposes of calculating these ratios, so a bank whose liquidity ratio was near the minimum when the tool was applied would be forced either to curtail its lending or sell investments (mainly government securities). Over time, the authorities attempted to restrict banks' degrees of freedom in adjusting to these calls by requesting that they were not met by selling investments. The scheme was first employed in April 1960 and, despite initially being

\footnotetext{
${ }^{18}$ There was no statutory basis for these requests; rather, the tool was operated on what amounted to a voluntary basis.
} 
looked on as "a temporary arrangement" (Capie, 2010), became a frequently-used lever of macroeconomic influence until its abandonment in 1980.

Supplementary special deposits The supplementary special deposits scheme - otherwise known as the "Corset" - was a system of non-remunerated reserve requirements tied to the rate of growth of each bank's interest-bearing sterling deposits or "eligible liabilities."19 If eligible liabilities grew faster than the prescribed rate, banks were required to place non-interest-bearing supplementary special deposits with the Bank. The deposit requirements were progressively larger the greater the overshoot over the prescribed rate, ranging from $5 \%$ to $50 \%$ of the incremental excess eligible liability growth. This had the effect of forcing banks either to accept lower profits or even losses on their marginal lending, or else to widen their lending spreads. The scheme applied to all listed banks and deposit-taking finance houses operating in the United Kingdom, but small institutions and Northern Irish banks were made exempt.

Credit ceilings Credit ceilings were frequently used in the 1960s and 70s as an emergency tool to reduce aggregate demand when balance of payments deficits reached crisis proportions. The modalities of these ceilings were typically set out in letters from the Governor of the Bank to the main banking and finance associations. The first such request in 1965 was purely qualitative, requesting that "the rate of increase in advances should decline" and specifying exempted loan categories the authorities wished to see favoured, such as those funding exports or manufacturing industry. Later requests contained explicit quantitative ceilings on the permissible rate of growth of credit over a specified period. Banks were sometimes given stronger incentives to comply: for instance, on 2 June 1969, the Bank announced that the rate of interest payable on special deposits would be halved until the ceiling at the time was met. The scheme applied to all forms of credit, including loans, overdrafts, discounting commercial bills, and leasing.

The practical difficulties of implementing credit ceilings were colossal. One problem

\footnotetext{
${ }^{19}$ Interest-bearing sterling deposits were taken to be the marginal source of funding to meet fluctuations in the demand for credit. For further detail, see Bank of England (1982).
} 
lay in extending the scope of the restraint beyond the clearing banks to relevant nonbank financial intermediaries. Restraint letters were sent to the Finance Houses Association, the Acceptance Houses Committee, and the London Discount Market Association - but the Bank had no formal power to enforce its requests to these nonbanks. A second problem arose when the clearing banks repeatedly overshot their lending targets, a fact that they plausibly put down to customers making use of existing credit facilities (Goodhart, 2014). ${ }^{20}$

Hire-purchase controls Hire purchase, the practice of purchasing durable goods via instalment credit, had become an increasingly important source of finance for consumer durables by the late 1950 s and the sector was growing rapidly. For instance, nearly a quarter of all new cars purchased at this time - and a much higher proportion of second-hand vehicles - were bought on hire purchase. The Board of Trade, a government department, exercised control over the terms of hire-purchase credit by stipulating minimum downpayments and maximum repayment periods for different categories of goods. These controls were used actively for much of the 1950s, and despite the Radcliffe Report's verdict that they were suitable for use only for short periods at times of emergency, continued to be used throughout the 1960s and 7os until their removal in 1982.

The principal advantage of hire-purchase controls lay in the reach they provided beyond the clearing banks to the specialist hire-purchase finance companies that funded approximately three quarters of the stock of hire-purchase debt. While the larger finance houses took some advances from banks, the majority of their funding came from issuing deposits. ${ }^{21}$ Controls on clearing banks' lending therefore had only a small effect on the provision of hire-purchase credit by finance companies. A second advantage of hire-purchase controls was that they could be targeted: policy changes were frequently directed at particular classes of good (e.g., cars, furniture etc.).

\footnotetext{
${ }^{20}$ The lending targets had no statutory basis, as was common with most financial regulation of the time. According to Capie (2010), the possibility of issuing a formal directive was raised, but dropped for fear of "changing the nature of the relationship between the Bank and the banks."

${ }^{21}$ In June 1962, deposits accounted for nearly two thirds of large finance houses' liabilities; smaller finance houses, by contrast, were much more reliant on bank advances to fund their balance sheets (Bank of England, 1962b).
} 


\subsection{Creating an aggregate credit policy index}

To analyse the effects of these instruments, we summarise the overall stance of policy via an aggregate credit policy index. We create this index in two steps: first, we create subindices that characterise the stance of each of the four instruments listed above; second, we summarise the overall variation across these sub-indices by the first principal component.

It is straightforward to characterise the stance of special deposits, as the tool was varied on a continuous scale. ${ }^{22}$ For hire-purchase restrictions, we create a continuous sub-index by taking the weighted average of controls applied to cars and other goods, where each in turn is given by the weighted average of minimum down-payment and the implied monthly instalments, that is,

$$
H P_{t}=\sum_{i} \omega_{i}\left[\mu d_{t}^{i}+(1-\mu)\left(\frac{1-d_{t}^{i}}{T_{t}^{i}}\right)\right],
$$

where $i$ is the category of good (cars, other consumer goods), $\omega_{i}$ is the weight applied to good $i$ in the index, $d_{t}^{i}$ is the required down-payment on good $i, T_{t}^{i}$ is the maximum repayment period on good $\mathrm{i}$, and $\mu$ is the weight received by the down-payment limit. In the index presented here we set $\omega=0.5$ and $\mu=0.25$. Figure 1a presents the time series of these first two continuous sub-indices. The monthly correlation between these sub-indicies over our sample is 0.3 .

We code the other tools in our set - credit ceilings and the supplementary special deposits scheme - by applying a o for dates where the policies were inactive, and applying $a+1$ incrementally when the policies were tightened. If a tool was tightened progressively, this implies an index whose value rises above 1 . In the case of the supplementary special deposits scheme, the index is either o or 1 . But for the credit ceilings tool, the index reaches 5 on one occasion. When credit ceilings are removed, we code the index as 0 , meaning that on one occasion the index falls by more than 1 . Tables 2 and 3 set out the policy changes that occurred and the mapping from these into index values. Finally, we take the first

\footnotetext{
${ }^{22}$ One complication is that banks were given around 6o days' notice of calls for special deposits before they were binding. So we could use either announcement dates or implementation dates in our sub-index. We choose the former as we expect that forward-looking banks would have begun adjusting their portfolios immediately after announcements.
} 
Figure 1: Time series of credit policy indices

The upper panel presents the time series of special deposit rates set by the Bank of England (blue line) and our index of hire-purchase restrictions set by the Board of Trade (red line). The lower panel presents the aggregate credit policy index.

(a) Special deposit rate and hire-purchase restrictions index

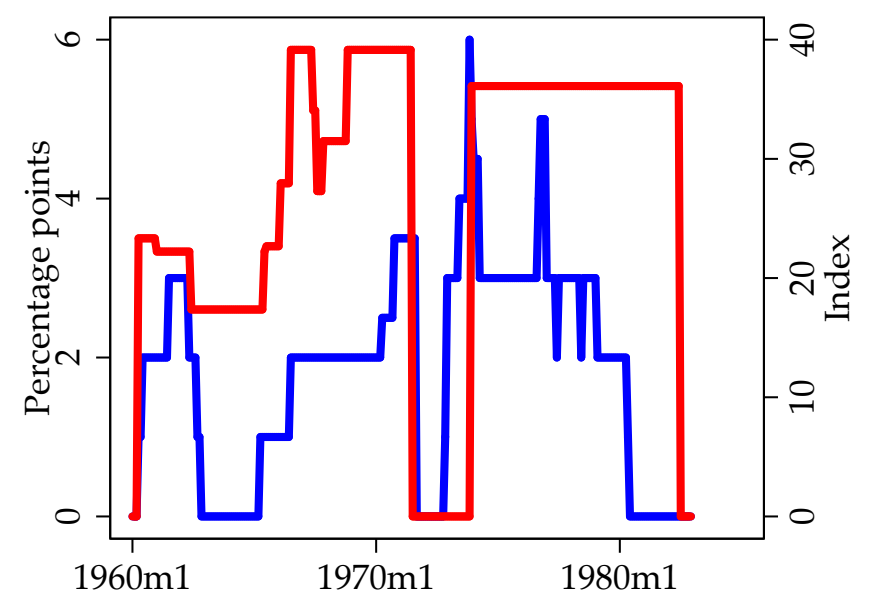

Calls for special deposits (LHS)

HP restrictions (RHS)

(b) Aggregate credit policy index

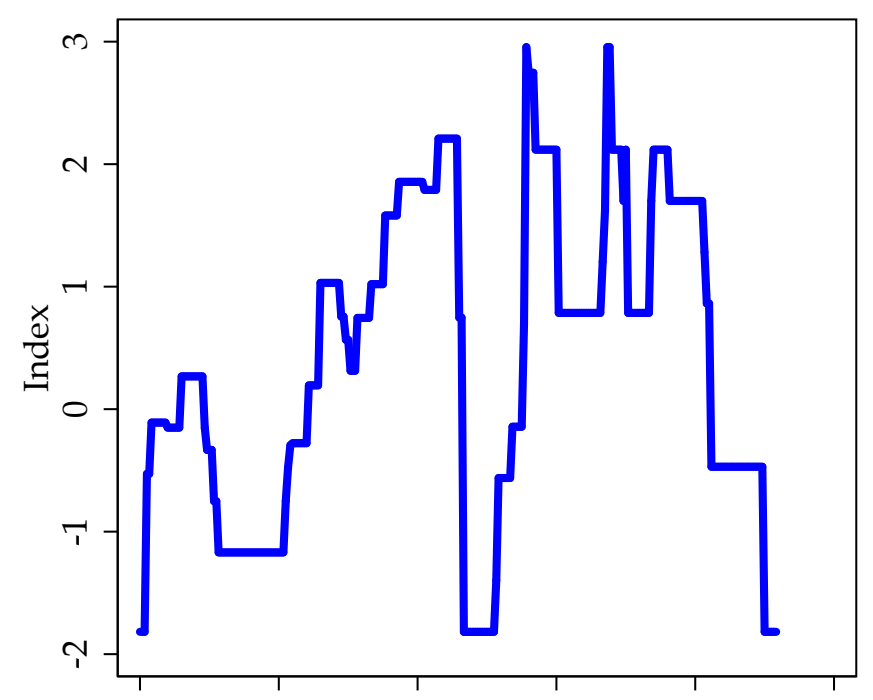

1960m1 1965m1 1970m1 1975m1 1980m1 1985m1

Notes: See section 3.2 for details. 
Table 2: Classifying credit ceiling notices

\begin{tabular}{|c|c|c|}
\hline Date & Description of the policy & Classification \\
\hline 1965 May 5 & $\begin{array}{l}\text { Governor's letter to Committee of London Clearing Bankers: aim was that advances to private } \\
\text { sector should not increase more than } 5 \% \text { during twelve months to March } 1966 \text {. Letters also sent } \\
\text { to other main banking associations. }\end{array}$ & 1 \\
\hline 1966 Feb 1 & $\begin{array}{l}\text { Governor's letter to Committee of London Clearing Bankers: until further review, advances, } \\
\text { acceptances and commercial bills should not rise above March } 1966 \text { levels. Letters also sent to } \\
\text { other main banking associations. }\end{array}$ & 2 \\
\hline 1967 Apr 11 & $\begin{array}{l}\text { Chancellor's Budget statement: ceiling on lending to private sector would be discontinued forth- } \\
\text { with for clearing and Scottish banks, and discontinued for other banks as and when suitable new } \\
\text { arrangements had been worked out. }\end{array}$ & 1 \\
\hline 1967 Nov 19 & $\begin{array}{l}\text { Government announced new measures of credit policy: lending at the latest date for which } \\
\text { figures are available will become the ceiling until further notice. }\end{array}$ & 2 \\
\hline 1968 May 23 & $\begin{array}{l}\text { Bank credit restriction notice: the restrictions requested last November should be modified so as } \\
\text { to achieve a greater reduction in lending to non-priority borrowers than has so far taken place. } \\
\text { Banks are asked not to allow lending to exceed } 104 \% \text { of the Nov } 1967 \text { level (i.e., roughly current } \\
\text { level) until further notice. }\end{array}$ & 3 \\
\hline 1968 Aug 30 & $\begin{array}{l}\text { Bank credit restriction notice: lending has fallen below the } 104 \% \text { ceiling; current restrictions must } \\
\text { continue to be rigorously enforced over the period ahead. }\end{array}$ & 3 \\
\hline 1968 Nov 22 & $\begin{array}{l}\text { Bank credit restriction notice: the clearing banks are now asked to reduce lending to } 98 \% \text { of its } \\
\text { mid-Nov } 1967 \text { level by mid-Mar 1969; other banks are asked to ensure their lending does not } \\
\text { exceed } 102 \% \text { of its Nov } 1967 \text { level by Mar } 1969 .\end{array}$ & 4 \\
\hline 1969 Jan 31 & $\begin{array}{l}\text { Deputy Governor's letter to Committee of London Clearing Bankers: little progress has yet been } \\
\text { made towards meeting the revised target for private sector lending set last November; we must } \\
\text { now re-emphasise the importance to achieving this target. }\end{array}$ & 4 \\
\hline 1969 May 31 & $\begin{array}{l}\text { Bank credit restriction notice: latest data show sharp reversal in progress in meeting lending } \\
\text { ceiling; Bank has decided to halve the rate of interest payable on Special Deposits from June 2nd } \\
\text { until banks comply with the ceiling. }\end{array}$ & 5 \\
\hline 1970 Apr 14 & $\begin{array}{l}\text { Chancellor's Budget statement: a gradual and moderate increase in lending that has hitherto } \\
\text { been subject to ceilings would be consistent with economic objectives; bank lending should not } \\
\text { rise by more than about } 5 \% \text { over } 12 \text { months from Mar } 1970 \text {. }\end{array}$ & 4 \\
\hline $1970 \mathrm{Jul} 28$ & $\begin{array}{l}\text { Bank credit restriction notice: latest data indicate lending is increasing at a faster pace than April } \\
\text { guidance. Clearing and Scottish banks reminded that April guidance remains in force and have } \\
\text { been asked to reduce lending growth accordingly. }\end{array}$ & 4 \\
\hline 1971 Mar 30 & $\begin{array}{l}\text { Chancellor's Budget statement: intention to put forward proposals to change techniques of mon- } \\
\text { etary control, but for now necessary to maintain guidelines on lending. Clearing and Scottish } \\
\text { banks asked that lending should not rise to mid-Jun } 1971 \text { by more than } 7.5 \% \text { above its mid-Mar } \\
1970 \text { level. }\end{array}$ & 4 \\
\hline 1971 Jun 30 & $\begin{array}{l}\text { Bank notice: proposed changes in monetary policy techniques not yet complete, so necessary to } \\
\text { extend the guidelines on lending. Clearers asked that lending in mid-Sep } 1971 \text { should not exceed } \\
\text { its mid-Mar } 1970 \text { level by more than } 10 \% \text {. Similar restraint applied to other banks. }\end{array}$ & 4 \\
\hline 1971 Sep 10 & Quantitative ceilings abandoned as part of Competition and Credit Control reform package. & $\mathrm{o}$ \\
\hline 1972 Aug 7 & $\begin{array}{l}\text { Governor's letter to banks: signs that demand from industry for bank finance is growing; I ask } \\
\text { that banks should make credit less readily available to property companies and non-industry } \\
\text { transactions to meet this demand. }\end{array}$ & $\mathrm{O}$ \\
\hline
\end{tabular}

principal component of these series to construct an aggregate credit policy index, which we use in our econometric analysis below. This aggregate index is presented in Figure $1 \mathrm{~b}$.

\subsection{Usage of monetary and credit policies}

To compare monetary and credit policy actions in our sample, Figure $2 a$ shows the time series data for annual changes in Bank Rate and annual changes in our aggregate credit policy index. Monetary and credit policies were clearly used jointly over the period, but the relationship is far from a one-to-one correspondence even when we look at annual changes. 
Table 3: Classifying announcements under the supplementary special deposits scheme

\begin{tabular}{|c|c|c|c|c|}
\hline Date & Base period & Permissible growth in IBELs & Rate of deposit & Classification \\
\hline 1973 Dec 17 & Oct-Dec 1973 & $\begin{array}{l}8 \% \text { over first six months; } \\
1.5 \% \text { thereafter }\end{array}$ & $\begin{array}{l}\text { Until Nov. 1974: } \\
5 \% \text { for excess of up to 1pp } \\
25 \% \text { for excess of } 1-3 p p \\
50 \% \text { for excess of over } 3 p p\end{array}$ & 1 \\
\hline 1975 Feb 28 & - & Scheme terminated & - & o \\
\hline 1976 Nov 18 & Aug-Oct 1976 & $\begin{array}{l}3 \% \text { over first } 6 \text { months } \\
0.5 \% \text { thereafter }\end{array}$ & As above & 1 \\
\hline 1977 Aug 11 & - & Scheme terminated & - & $\mathrm{o}$ \\
\hline 1978 Jun 8 & Nov 1977-Apr 1978 & $\begin{array}{l}\text { 4\% during Aug - Oct 1978; } \\
1 \% \text { thereafter }\end{array}$ & As above & 1 \\
\hline 1980 Aug 11 & - & Scheme terminated & - & o \\
\hline
\end{tabular}

Table 4: Summary statistics on the usage of monetary and credit policy tools

\begin{tabular}{|c|c|c|c|c|}
\hline & & Full Sample & Pre-September 1971 & Post-August 1971 \\
\hline \multirow[t]{5}{*}{ Bank Rate } & Standard Deviation & $3 \cdot 5$ & 1.2 & 3.2 \\
\hline & Number of Tightenings & 33 & 9 & 24 \\
\hline & Average Tightening Size & 1.5 & 1.3 & 1.6 \\
\hline & Number of Loosenings & 62 & 16 & 46 \\
\hline & Average Loosening Size & 0.7 & 0.6 & 0.7 \\
\hline \multirow[t]{5}{*}{ Credit Policy Index } & Standard Deviation & 1.3 & 1.1 & 1.4 \\
\hline & Number of Tightenings & 25 & 14 & 11 \\
\hline & Average Tightening Size & 0.6 & 0.4 & 0.8 \\
\hline & Number of Loosenings & 22 & 10 & 12 \\
\hline & Average Loosening Size & 0.7 & 0.4 & 0.9 \\
\hline \multirow[t]{2}{*}{ Both tools } & Number of moves in same direction & 15 & 5 & 10 \\
\hline & Number of moves in opposite direction & 8 & 6 & 2 \\
\hline
\end{tabular}

Source: Authors' calculations.

The correlation between monthly changes in these variables is much lower still, with a contemporaneous correlation coefficient of 0.2 , as seen in Figure $2 b$.

Table 4 presents a range of sample statistics on the usage of these policy tools. Over the full sample, changes in the credit policy index are roughly evenly distributed between tightenings and loosenings, whereas the distribution of changes in Bank Rate is skewed, with almost twice as many loosenings as tightenings. Bank Rate hikes are typically twice as large as cuts, however. The frequency of changes in Bank Rate is about three times higher post-1971 relative to pre-1971, whereas credit policy usage is roughly constant in both sub-samples. Consistent with Figure $2 a$, the instruments were typically adjusted in the same direction: over the full sample, there were 15 within-year moves in the same direction; the policies were moved in opposite directions on 8 occasions. 
Figure 2: The co-movement of monetary policy and credit policy

The upper panel presents 12-month changes in Bank Rate (blue line) and the credit policy index (red line). The lower panel presents the cross-correlation between the monthly change in Bank Rate and leads and lags of the monthly change in the credit policy index.

(a) Bank Rate and the aggregate credit policy index

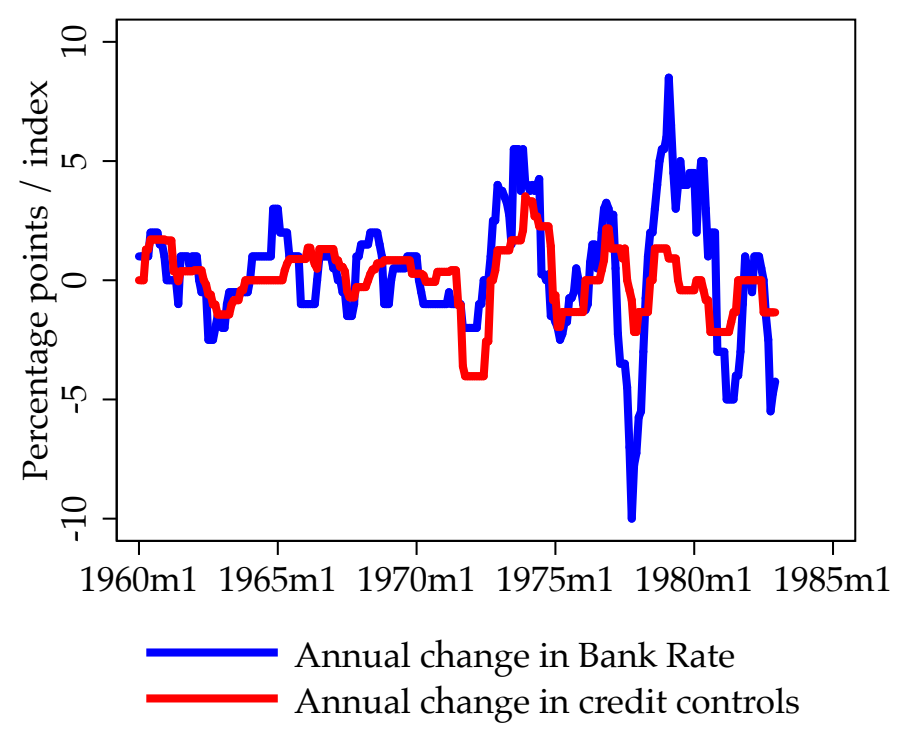

(b) Lead-lag relationship between Bank Rate and credit policy index

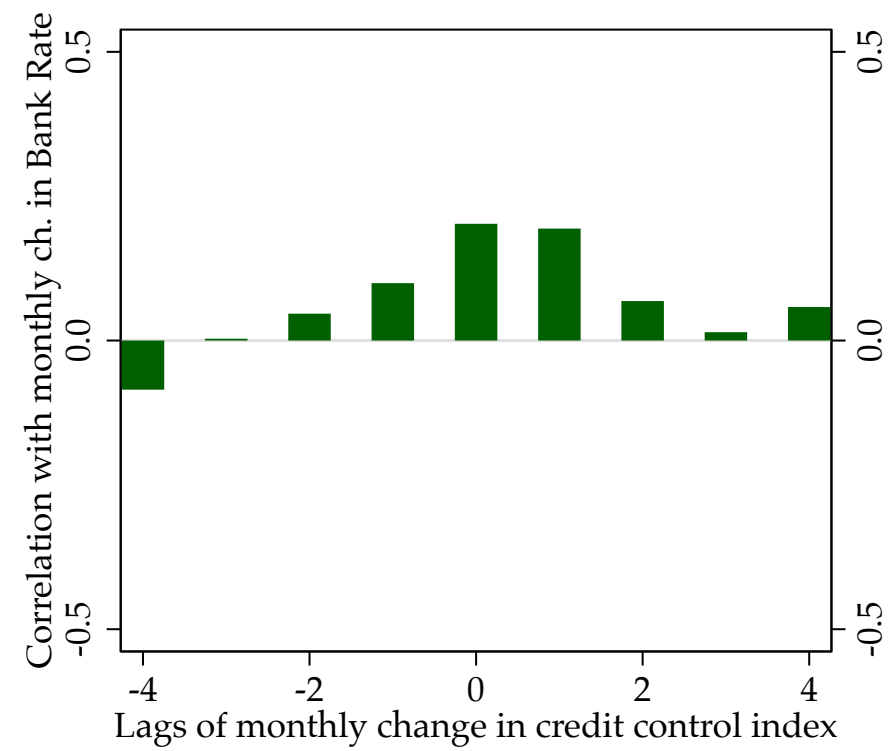

Notes: See text. 


\subsection{The macroeconomic and financial backdrop}

Figure 3 presents time series in the sample period for four key UK macroeconomic indicators used in our analysis: manufacturing output; consumer price inflation; bank lending; and Bank Rate. There were pronounced fluctuations in all these variables over the period. It is particularly noticeable that real activity exhibited very short cycles: activity peaked locally in 1960, 1963-64, 1968, 1970, 1972, 1974, 1976, 1978-79, and 1982. Similar cycles were observed in bank lending, although the stand-out event of the period was the boom in credit that followed the November 1971 relaxation in credit controls via Competition and Credit Control and Chancellor Barber's 1972 "dash for growth" budget.

On the nominal side of the economy, the history of this period bifurcates sharply in the early 1970s. Up until the early 1970s, there was a clear nominal anchor provided by the Bretton Woods exchange rate system. The ongoing risk of exchange rate crises, which crystallised several times over the period, disciplined the use of monetary policy, with policy moves often related to balance-of-payments pressure on sterling. Following the end

of Bretton Woods, the monetary policy framework was far less clear and the relationship between policy and its objectives much looser. Inflation began to increase sharply following the first oil shock in 1973, peaking at an annualized rate of around $25 \%$ in 1975 . After falling back a little, it increased further once more in 1979-80 following the second oil price shock. Interest rates followed a similar profile, except with a lag.

\section{Identification Strategy and Data}

The central challenge for identifying the effects of monetary policy on macroeconomic variables such as output and inflation is that policies tend to be set in response to actual and prospective movements in these variables. For this reason, as is well known, naïve regressions of variables of interest on policy variables will likely yield biased coefficient estimates. For example, it is often observed that prices tend to rise following increases in policy rates. This could, in part, reflect policymakers tightening monetary policy because 
Figure 3: Behaviour of key macroeconomic variables over the period

The figure presents time series of four macroeconomic indicators over our sample period.

(a) Manufacturing output

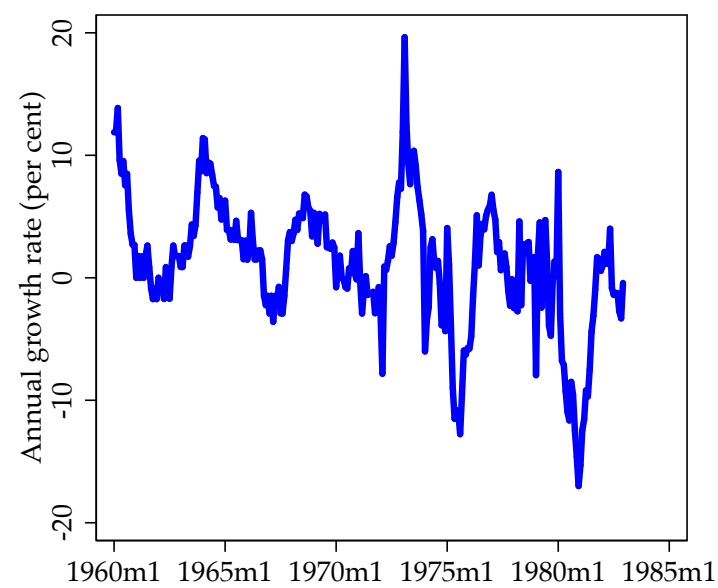

(c) Bank lending

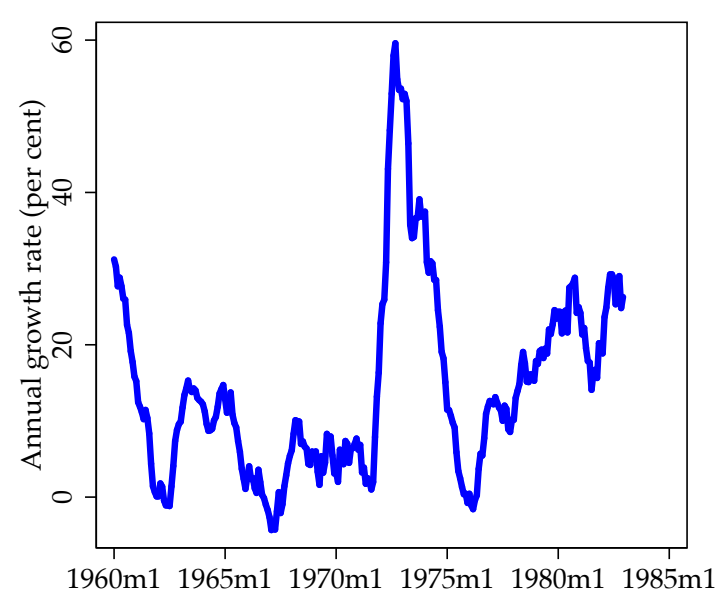

(b) Consumer prices

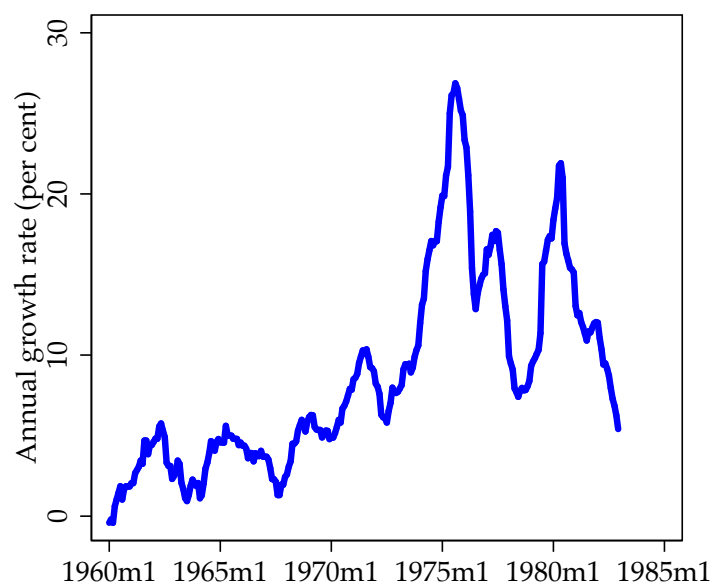

(d) Bank Rate

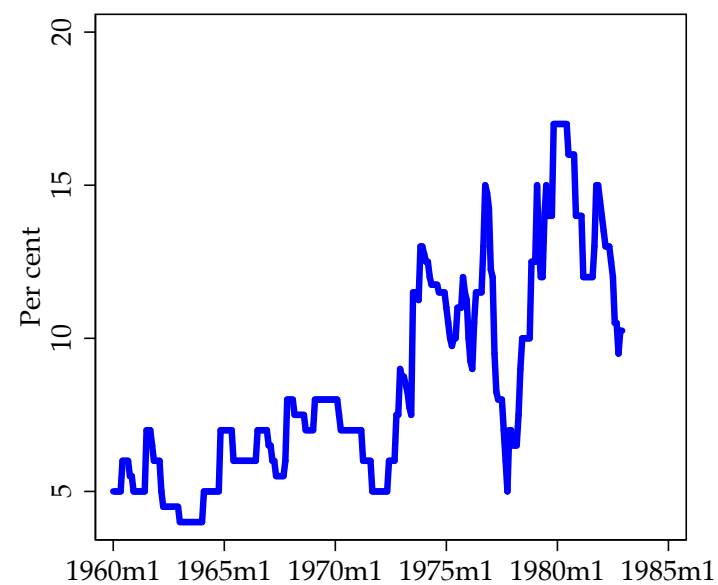

Notes: See text. 
they expect inflation to rise, rather than monetary policy causing prices to rise. This section explains our approach for overcoming this pervasive problem of reverse causality. In particular, we employ a novel identification strategy, which we term Factor-Augmented Local Projection (FALP).

\subsection{Identification strategy}

Motivation for our approach One way of trying to tackle the bias described above is to control for the forecasts which policymakers were using to set policy. Romer and Romer (2004) introduced this technique to the monetary policy literature. They collected "Greenbook" forecasts compiled by the staff of the Federal Reserve Board and showed that the Federal Funds Rate varies with lags and forecasts of output growth, inflation, and the unemployment rate, and changes in these forecasts since the previous set. They then purged the policy rate series of this systematic component to obtain a series of residual monetary policy shocks orthogonal to the forecast information set. In a second-stage autoregressive distributed lag (ARDL) model, they regressed variables of interest such as growth in industrial production on these residuals. They found considerably larger effects of policy than in the previous empirical literature.

Cochrane (2004) points out two ways in which the Romer and Romer (2004) method can be simplified. First, he argued that the only right-hand-side variables which are needed in the first-stage regression are forecasts of the dependent variable in the second-stage regression. The underlying problem is omitted variable bias, so all that is needed is to control for the variables which are correlated with changes in policy and the second-stage dependent variable. Including forecasts of the dependent variable in the second-stage regression should be sufficient.

Second, he suggested using a local projection approach to computing impulse response functions (IRFs), as in Jordà (2005), instead of the ARDL. Local projections (LPs) are more flexible than multi- and univariate autoregressions, not least because the user does not need to take a stance on the number of autoregressive lags to be included, something which 
Coibion (2012) finds makes a large difference to the estimates of the size of the effects of monetary policy. LPs can also be estimated one equation at a time, and thus can be parametrically less demanding in many cases.

Another popular method for identifying monetary policy shocks, introduced by Bernanke et al (2005), is to estimate structural vector autoregressions that include a small number of estimated factors extracted from very large datasets. These factors are intended to summarise the information sets on which policymakers' expectations and actions are based. Factors have been shown to produce good forecasts (Stock and Watson, 2002). Indeed, Bernanke and Boivin (2003) show that the Fed's forecasting performance could have been improved upon by incorporating such information. Bernanke et al (2005) refer to this as the factor-augmented vector autoregression (FAVAR) approach.

Our approach blends these two methods, controlling for both forecasts and factors. We have two motivations. First, we face a difficulty not encountered by Romer and Romer: over this period, the UK authorities did not prepare forecasts immediately ahead of each policy decision. In some cases in our sample, for instance, the gap between a policy move and the latest available forecast is several months. Were we only to control for such stale forecasts, we may fail to take into account relevant information that led to subsequent policy changes, introducing a bias into our estimates.

Our second motivation is that forecasts may not be the best available summary of all the information used by policymakers at the time. Even large macroeconometric models only contain a subset of the variables monitored by policymakers. This is consistent with Bernanke and Boivin's finding that factors contain information about the future over and above that contained in official forecasts.

Factor-Augmented Local Projection (FALP) specification To calculate the causal effects of monetary and credit policy, we estimate local projections at each horizon, regressing our response variables on policy variables and conditioning on the forecasts and factors. 
Specifically we estimate

$$
\begin{aligned}
\Delta y_{i, t, t+h}= & \alpha_{i, h}+\beta_{i, h} \Delta \text { policy }_{t}+\gamma_{1, i, h} \Delta \text { policy }_{t-1}+\gamma_{2, i, h} \Delta \text { policy }_{t-2} \\
& +\sum_{j=1}^{J} \gamma_{i, h, j} E_{t}\left[\Delta y_{j, t}\right]+\sum_{k=1}^{K} \sum_{l=1}^{L} \eta_{i, h, k, l} F_{k, t-l}+\zeta_{i, h} \text { month }_{\mathbf{t}}+\epsilon_{i, h, t}
\end{aligned}
$$

where $\Delta y_{i, t, t+h} \equiv y_{i, t+h}-y_{i, t}$ is a response variable of interest (e.g., $\log$ GDP) indexed by $i$, $h$ is the horizon in months, $\Delta$ policy $_{t}$ is a 2-vector of policy changes (changes in Bank Rate and changes in the aggregate credit policy index, as in Section 3.2), $E_{t}\left[\Delta y_{j, t}\right]$ and $F_{k, t-l}$ are the forecasts and factors as described below, and month $_{t}$ is a set of time dummies. We obtain local projections at horizons up to four years and chart the main impulse response function coefficients of interest $\beta_{i, h}$, these being the estimates of the average response to a unit change in each of the two policies at the horizon in question. $23,24,25$

We use the latest available forecasts as conditioning variables. As will be described in Section 4.2, below, these are forecasts of GDP, the consumer price deflator, and the current account (i.e., $J=3$ ). We pick these variables because they correspond closely to those outcome variables which policymakers were ostensibly trying to control in the period. These variables are reported quarterly. In months for which forecasts are available, we use the forecast of the change in each variable from the quarter before the forecast was made to the quarter half a year ahead. This procedure follows Cochrane (2004). ${ }^{26}$ In months without forecasts, we pick the latest available forecast and adjust the timing as necessary

\footnotetext{
${ }^{23}$ Standard errors are calculated using the Newey-West estimator, with the lag correction increasing in the horizon in question. We have not yet factored in the uncertainty stemming from the estimation of the factors, but will do so in a later version.

${ }^{24}$ This specification is in the spirit of Cochrane (2004) because of its parsimony and because it is a series of local projections rather than a conventional (vector) autoregression. Indeed, we simplify even further relative to previous methods, by combining the two stages of estimating shocks and then using these shocks in a second-stage regression into one step.

${ }^{25}$ We also note that, even though the papers were written independently, in a similar spirit to our paper the vast survey chapter by Ramey (2016, p. 41 and Figure 3.2B) also briefly explores among several identification schemes the idea of combining recursive LPs with FAVAR controls at one point.

${ }^{26}$ We sum the forecasts for reasons of parsimony. For example, in January 1960 the forecasts are for growth between $1959 Q_{4}$ and $1960 Q_{3}$, rather than separate forecasts for growth in 1960 Q1, Q2 and Q3.
} 
should the forecast have been made in a different quarter. ${ }^{27}$

The factors are extracted from a large dataset, described in Section 4.2, using principal component analysis. We follow Stock and Watson (2002) in using the Bayesian Information Criterion (BIC) to choose the number and lags of factors used. The BIC suggests different numbers of factors and lags for different response variables and horizons. Rather than vary the specification in this way, we choose the most parsimonious specification for our baseline results. This includes three factors and one lag - i.e., $K=3, L=1$. We show how the results differ in a set of robustness checks in a Supplementary Appendix.

The timing assumptions in our specification are more conservative than in most recursive monetary policy VARs. Although we assume policymakers react to forecasts available in the same month, we assume a lag of one month before they can act on the data summarised in the factors and that there is no contemporaneous effect of policy on our response variables. Our motivation for this is that some policy changes took place early in the month and others right at the end. For policy changes early in the month, it is unrealistic to assume that policymakers could observe the evolution of the data in that month. ${ }^{28}$ Conversely, it is unrealistic to expect movements in response variables (aside from some asset prices) during a month in which a policy change was made late on.

\subsection{Data}

Macroeconomic variables In Section 5, we focus on four response variables: bank lending, manufacturing output, consumer prices, and the trade balance to GDP ratio. Our nominal bank lending series is sterling lending to UK residents by UK resident banks. From 1960 until 1971, this is not available, so our proxy is lending by Clearing Banks (the big British banks of the time). In practice, this is likely to capture the vast majority of UK bank

\footnotetext{
${ }^{27}$ For example, the most recent forecast available in April 1981 was made in March 1981. Because this is a different quarter, we need to use the forecasts of the change between $Q_{1}$ and $Q_{4} 1981$ rather than $Q_{4} 1980$ and $Q_{3} 1981$.

${ }^{28}$ Of course, the same point could be made about forecasts, but given lags in the forecasting process, we think it reasonable that forecasts published a few weeks after a policy move are good summaries of the information available to policymakers at the time of the policy move. If these forecasts incorporate the policy news, this ought to depress our estimates of the effect of policy toward zero.
} 
sterling lending to UK residents. Over the course of our sample, lending to non-financial corporations made up the majority of UK sterling bank lending. The sources for our bank lending series are hard copies of the Bank of England Statistical Abstract and the Quarterly Bulletin. We digitised the real manufacturing output series from hard copies of the UK Central Statistical Office (CSO) Monthly Digest of Statistics. The consumer price index has the same ultimate source, although the successor to the CSO, the Office for National Statistics (ONS) has already digitised the series. ${ }^{29}$ The trade balance is also taken from hard copies of the Monthly Digest of Statistics and we divide by the latest (i.e., 2016) vintage of nominal GDP. $3^{30}$

Forecasts A key contribution of this paper is a new dataset of forecasts of UK output, inflation, and the current account between 1960 and 1982. As detailed official forecasts were not published over this period, we collected unpublished HM Treasury forecasts by hand from the National Archives and digitized them. Treasury forecasts were typically produced three times a year. ${ }^{31}$ For this reason, we supplemented official forecasts with those of the National Institute of Economic and Social Research (NIESR), a prominent independent research institute, which were published each quarter. ${ }^{32}$ In total, our dataset contains 126 complete sets of forecasts, almost one every other month. ${ }^{33}$

Figure 4 presents the forecasts we use in the analysis. While there are some exceptions — notably the 1980 growth forecasts - Treasury and NIESR forecasts are highly correlated over the period (the correlation coefficient for the GDP forecasts is o.8), suggesting that the latter are good proxies where official forecasts are unavailable. This is similar to the finding

\footnotetext{
${ }^{29}$ Allen et al. (2004).

${ }^{30}$ We simply divide the quarterly figures into three to obtain a monthly GDP series. Doing this and using the latest vintage is very unlikely to make much difference to the pattern of the trade balance to GDP ratio as the variation in this series is so heavily driven by the numerator, not the denominator.

${ }^{31}$ Regular forecasts tended to be in February, July and November. For most of the years in our sample, these were recorded in Cabinet Office Committee files. However, HM Treasury files also have a number of draft forecasts, some of which we also include (particularly in years with a low number of forecasts in the Cabinet Office files).

${ }^{32}$ NIESR forecasts were published quarterly, except in 1960 and 1961 when they were published every other month.

${ }^{33}$ To obtain forecasts for the current account to GDP ratio, we divide by the latest vintage of the nominal GDP data as neither HM Treasury nor NIESR produced nominal GDP forecasts for most of this period.
} 
of Cloyne and Hürtgen (2014), who find that NIESR forecasts are highly correlated with the Bank of England's Inflation Report projections for the period in which both are available. Appendix I summarise a series of articles reviewing the quality of NIESR forecasts over this period, finding that they were comparable in quality with other leading forecasts. 34

Factors We have also constructed a new monthly macroeconomic dataset for the UK from 1960 to 1982 . This 67 -variable dataset was deployed using principal components analysis to estimate the factors used as additional controls in the local projections.

The data span most of the key series which policymakers followed then and now, although because the dataset is monthly it is somewhat light on measures of demand and output, many of which are only produced at quarterly frequency. Table Ai in Appendix 2 lists the full dataset used to construct the factors in the FALPs, and describes the transformations we performed before estimating the factors.

The series in the monthly dataset were pulled together from a wide variety of intermediate sources, although a high proportion of the series were originally published by the CSO or the Bank of England. About half of the series were manually transcribed at least in part from original publications. The most frequently used secondary sources were Hills et al. (2015) and Thomson Reuters Datastream.

Policy variables We obtained Bank Rate and Minimum Lending Rate (the main policy rate from 1972 to the end of our period of study) from the Bank of England website and manually collected data on calls for special deposits from editions of Financial Statistics published by the CSO. Data on hire-purchase regulation came from the National Institute Economic Review and various publications by the Board of Trade, which operated the policy. The series on the introduction and removal of credit ceilings and the supplementary special deposits scheme were manually compiled based on Bank of England Quarterly Bulletin accounts.

\footnotetext{
${ }^{34} \mathrm{An}$ additional nugget of anecdotal evidence supporting our claim that NIESR forecasts were good proxies for official sector forecasts is that lead NIESR forecaster Leslie Dicks-Mireaux was hired by the Bank in this period.
} 


\section{Figure 4: Forecasts}

The figure presents time series of the forecasts of GDP growth, the consumption deflator, and the current account produced by HM Treasury and the National Institute for Economic and Social Research (NIESR). Each forecast is the sum of the nowcast and the one- and two-quarter ahead forecasts and we have annualised them for ease of interpretation.

(a) GDP growth

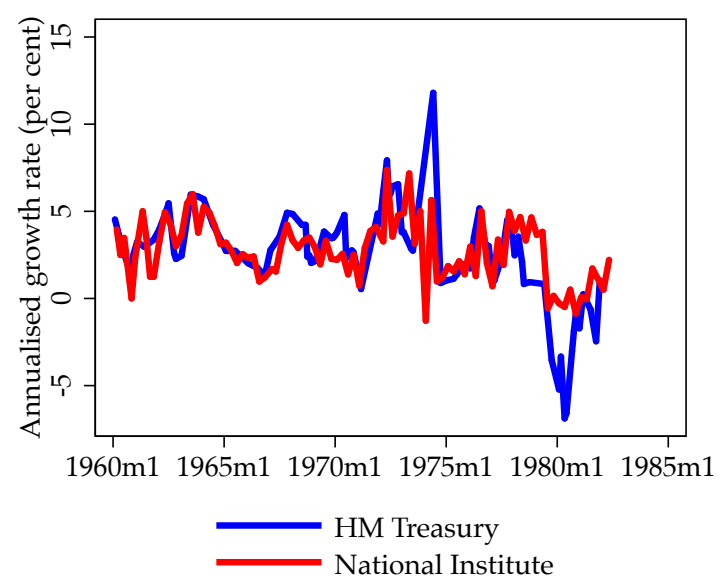

(b) Consumption deflator

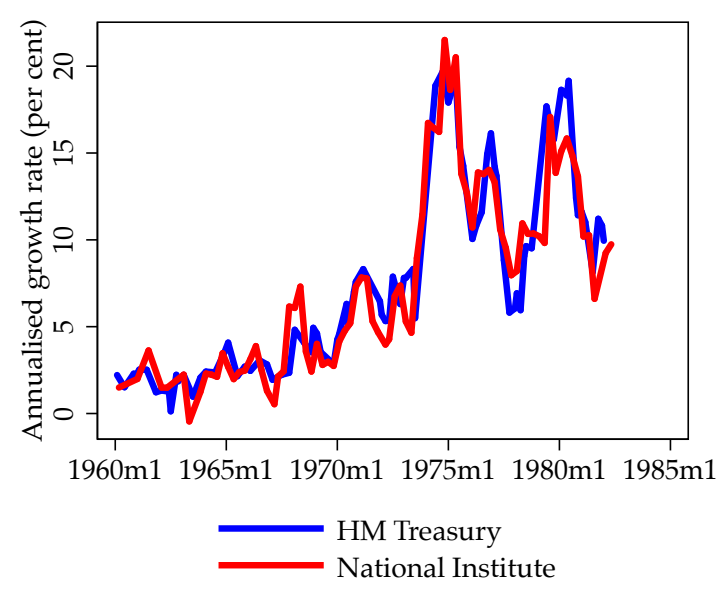

(c) Current account

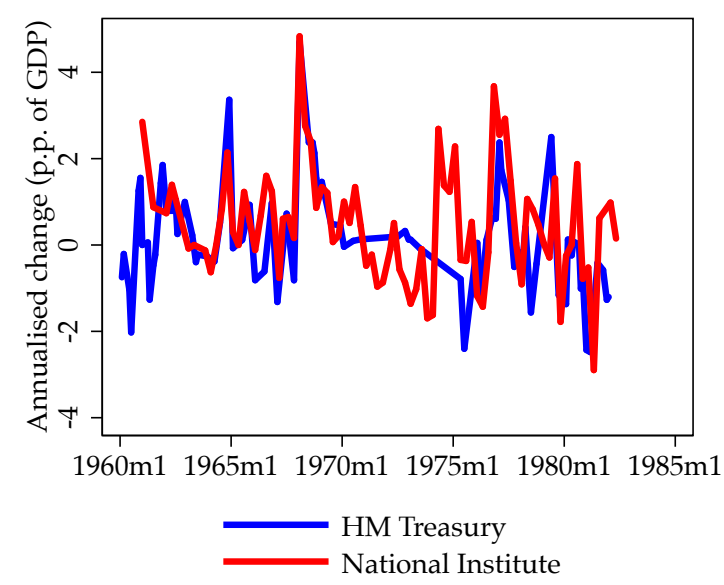

Notes: Missing data are interpolated. See text. 


\section{Main Results}

In this section, we describe the main results of the paper. After showing the exogenous movements in Bank Rate and credit controls implicit in our empirical specification, we focus on characterizing the responses of output, inflation, credit, and the trade balance, the main targets of policy in this period. We subject all our findings to a battery of robustness tests, which we summarize below. First, we examine the sensitivity of our results to the number of factors and associated lags included as control variables. In particular, we assess impulse responses for the full range of factor/lag combinations suggested by the BICs (three factors and one lag to seven factors and two lags). Second, we compare the results obtained before and after September 1971: there are good reasons why the results may differ given the changes in exchange rate regime, changes in the structure of the banking system following Competition and Credit Control, and divergent inflation behavior. Third, we compare our baseline results with those from specifications that only include factors or forecasts. A Supplementary Appendix presents full results from these exercises.

\subsection{Exogenous movements in monetary and credit policy}

It is easy to back out the exogenous movements of monetary and credit policy from our one-stage empirical specification: these are simply the residuals of a regression of the policy series on each other, the forecasts and the factors. The top row of Figure 5 shows the monthly residuals for each policy and the bottom row shows the twelve-month rolling sum compared with the twelve-month change in the policy series (which includes endogenous changes). The top row shows that we have a lot of variation in our exogenous policy series in our sample. Indeed, it is immediately clear from the bottom row that most of the movement in Bank Rate and especially credit controls is exogenous to our model. This likely reflects two phenomena. First, policy changes were often driven by exchange rate concerns, which may not have been strongly correlated with expected developments in the domestic economy. This source of variation is very useful in helping us estimate the causal 
Figure 5: Exogenous movements in monetary and credit policy

The figure presents the exogenous components of monetary and credit policy.

(a) Bank Rate (monthly change)

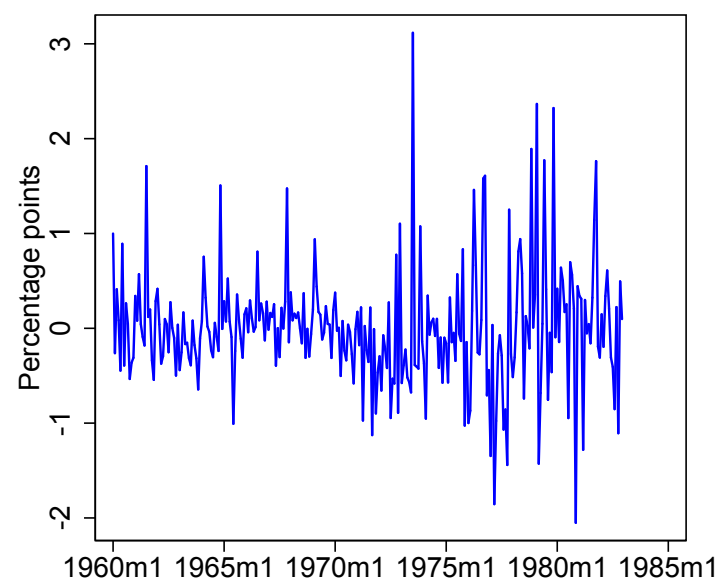

(c) Bank Rate (annual change)

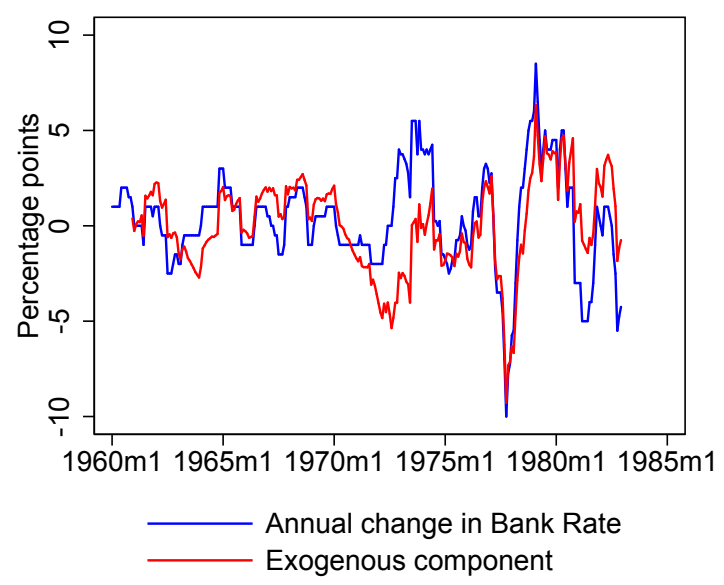

(b) Credit controls (monthly change)

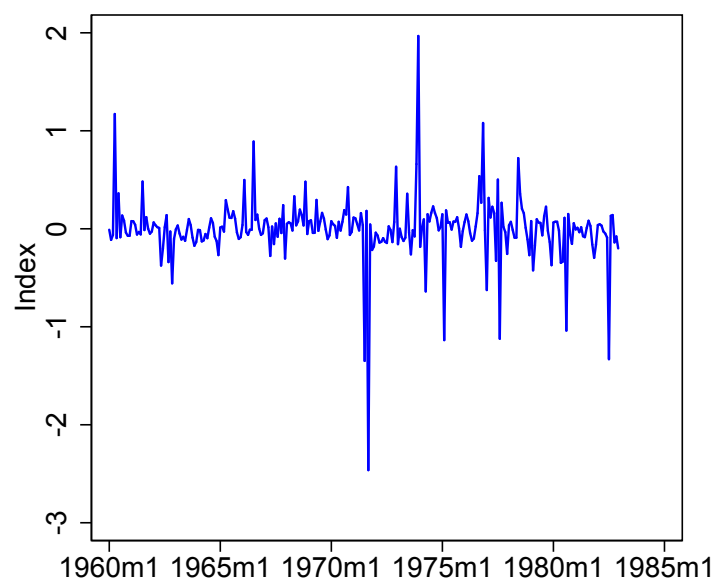

(d) Credit controls (annual change)

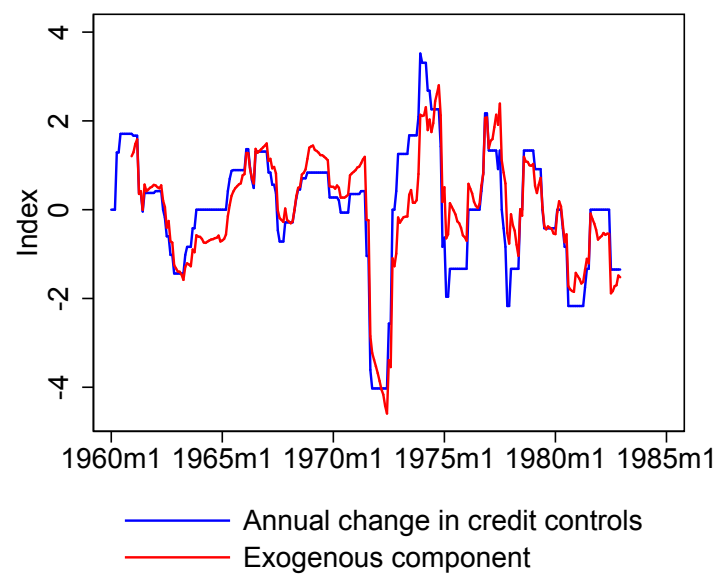

Notes: See text. 
impact of policy. Second, some of the variation in our exogenous series may in fact reflect changing policy rules. This source of variation may be problematic for our estimates, which is why we split the sample in one robustness exercise.

The exogenous Bank Rate series broadly matches up to the historical narrative, with policy becoming significantly looser in the early 1970 s as Heath blocked monetary tightening during the Barber Boom (Needham, 2015) and again in 1977 when policymakers sought to prevent sterling appreciation, while the late 1970s saw an abrupt move towards contractionary policy. The credit control series has a number of mini-cycles, but the loosening in 1971 and tightening in $1973-74$ stand out.

\subsection{The causal impact of Bank Rate shocks}

Figure 6 presents estimated impulse responses of key macroeconomic variables following a I percentage point increase in Bank Rate. Manufacturing output is estimated to decline persistently, with the mean response declining by around 2 per cent after 24 months. Thereafter, manufacturing output recovers to its pre-shock level. The consumer price level takes longer to adjust; prices are broadly unchanged for 20 months, and then begin to decline persistently, and are roughly 3 per cent lower after 4 years. The response of bank

lending cannot be distinguished statistically from zero. The trade balance is estimated to improve by around 0.75 per cent after two years, this direction being in line with typical Mundell-Fleming predictions under a Bretton Woods-style fixed-rate regime (in which income effects operate, but expenditure switching does not). The results are broadly in line with the empirical literature on the effects of monetary policy. Quantitatively, the estimated responses for output and inflation are comparable to Cloyne and Hürtgen's (2014) estimates for the period 1975 to 2007. Our results are also within the range of those reported in the U.S. literature, with larger responses than Bernanke et al. (2005), but smaller responses than Romer and Romer (2004).

The robustness exercises we conduct do not, in the main, give us cause to doubt our qualitative results, although the response of bank lending is sensitive to the number of 
Figure 6: Responses of key variables to a Bank Rate shock

The panels present estimated impulse responses of each variable to a percentage point increase in Bank Rate. The red bold line shows the mean estimated response; the dark grey region shows the \pm 1 standard error confidence interval; the light grey region shows the \pm 2 standard error confidence interval.

\section{(a) Response of manufacturing output}

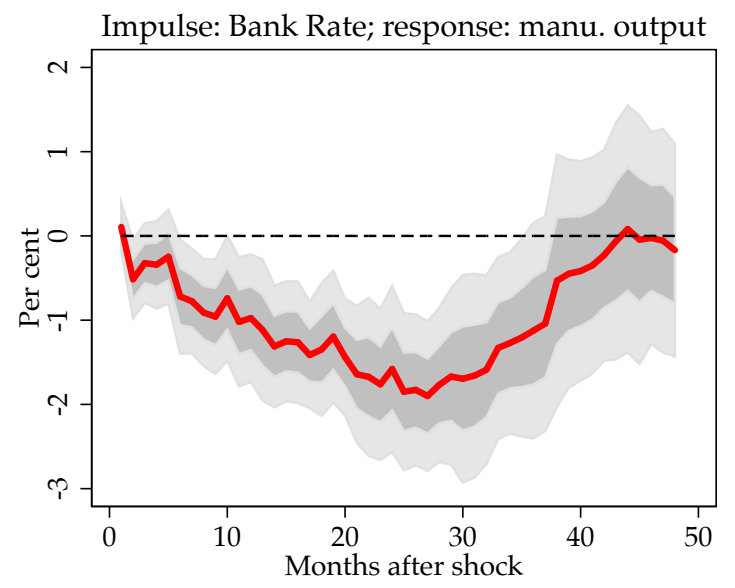

(c) Response of bank lending

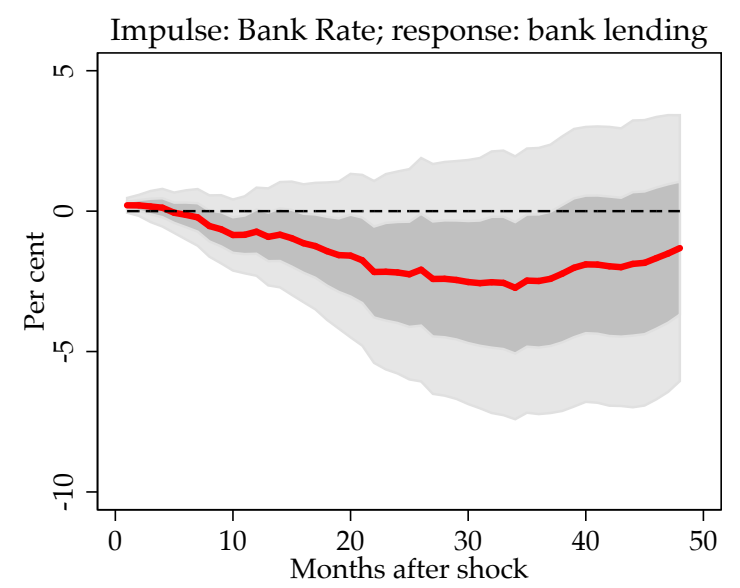

(b) Response of CPI

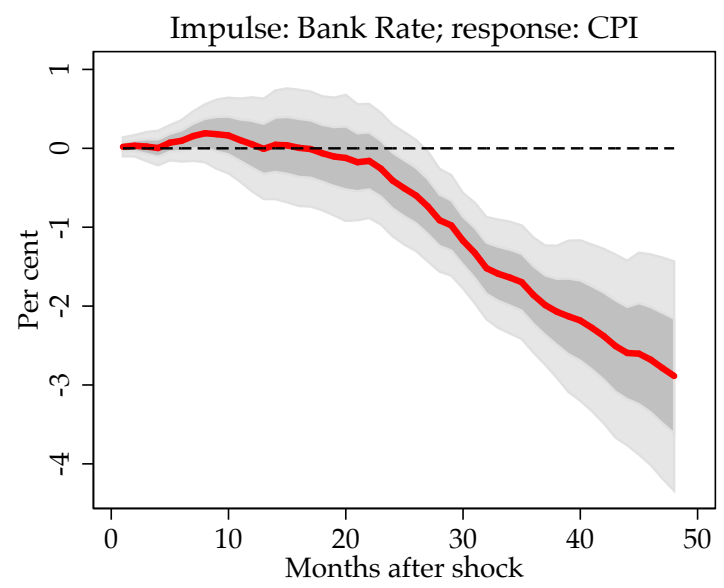

(d) Response of trade balance

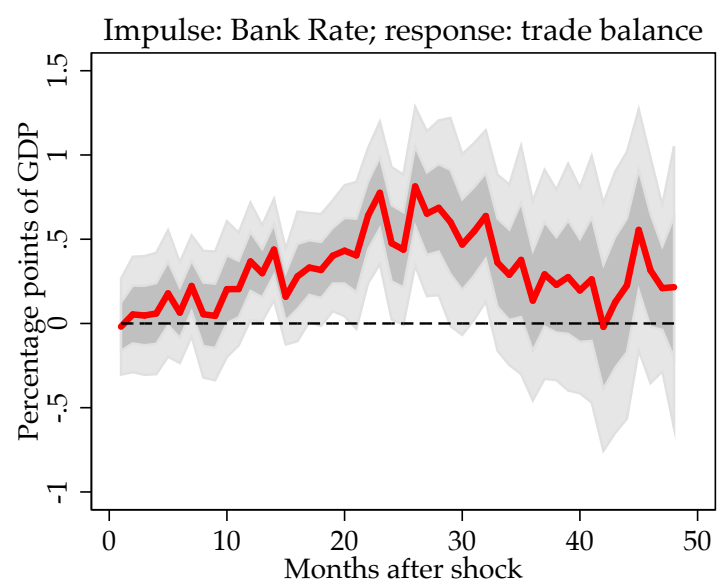

Notes: See text. 
factors and lags included (Figure A1 in the Supplementary Appendix) and is very different across the two subsamples (Figures A9 and A10). Quantitatively, the responses tend to be somewhat larger in the early subsample (Figures A9-A16). The baseline and factoronly approaches yield very similar results (Figures A25-A32), as do the baseline and forecast-only responses (Figures $\left.\mathrm{A}_{41} 1-\mathrm{A} 48\right)$.

We interpret our results as running contrary to the Radcliffe Committee's doubts about the efficacy of conventional monetary policy: our findings indicate that monetary policy had a stable transmission mechanism to the key policy objectives of the time: stability of output, prices, and external balance. Moreover, the causal impacts we identify are close in magnitude to the consensus impacts seen in today's contemporary macro literature.

\subsection{The causal impact of credit policy shocks}

Figure 7 presents estimated impulse responses to a 1 unit increase in the credit policy index (equivalent to 0.8 of the standard deviation of the series). As this is an index, the size of this increase does not have a natural interpretation. But to put it into perspective, the standard deviation of the credit policy index is slightly less than half of the standard deviation of Bank Rate over our sample (Table 4). In response, bank lending is estimated to decline persistently and considerably, falling by over 10 per cent after 2 years. Manufacturing output is also estimated to decline, falling by almost 3 per cent after 2 years. Consumer prices are estimated to increase, although the uncertainty surrounding this estimate is large.

Taken at face value, this co-movement is consistent with shocks to the credit policy index influencing both aggregate demand and supply. This would be in line with the findings of Glocker and Towbin (2012), who find that shocks to reserve requirements reduce lending and output, but leave prices broadly unchanged or higher. The trade balance is estimated to improve by around 1 per cent after 2 years.

However, the robustness exercises suggest that there is some uncertainty surrounding the estimated impacts for credit controls. Although most results are stable as we vary the factors (Figures A5-A8 in the Supplementary Appendix), time periods (Figures A17-A24), 
Figure 7: Responses of key variables to a credit policy shock

The panels present estimated impulse responses of each variable to variable to a 1 unit increase in the credit policy index (equivalent to 0.8 of the standard deviation of the series). The red bold line shows the mean estimated response; the dark grey region shows the \pm 1 standard error confidence interval; the light grey region shows the \pm 2 standard error confidence interval.

\section{(a) Response of manufacturing output}

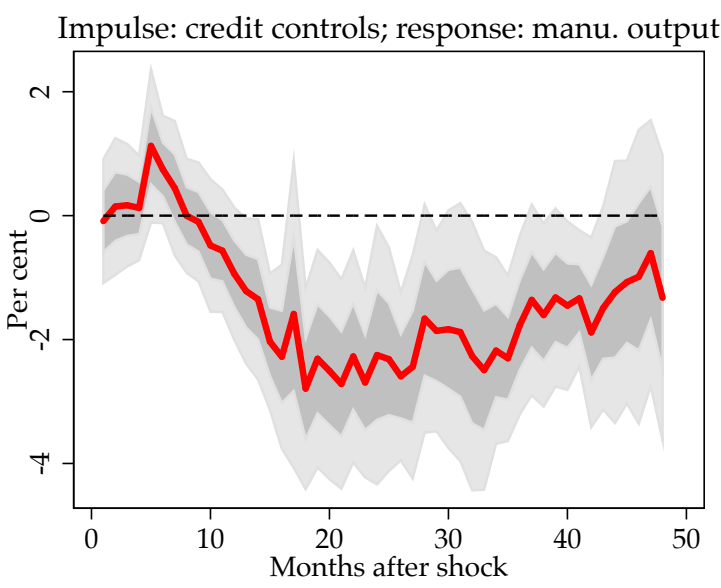

(c) Response of bank lending

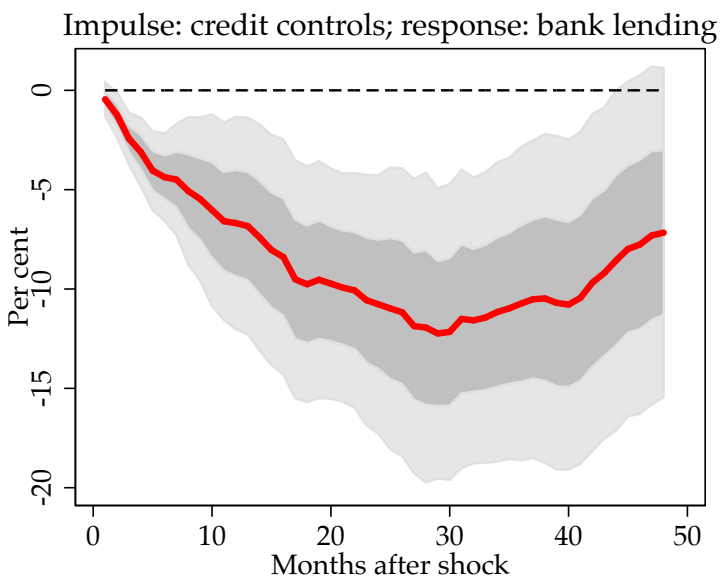

(b) Response of CPI

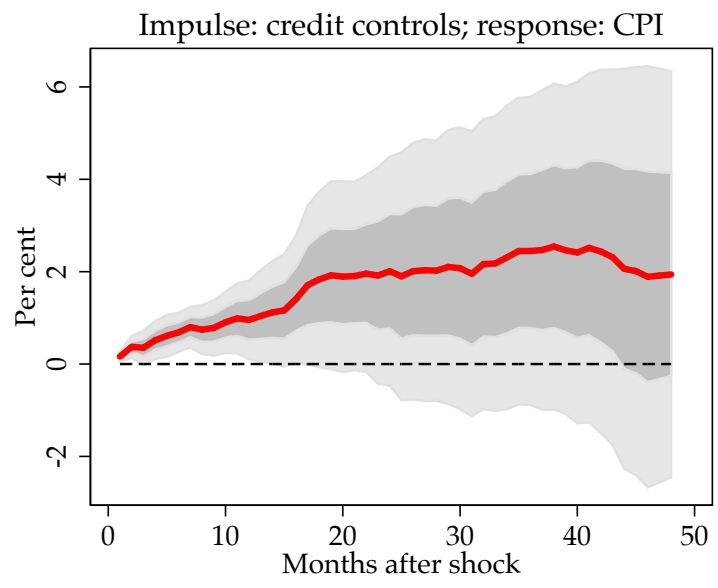

(d) Response of trade balance

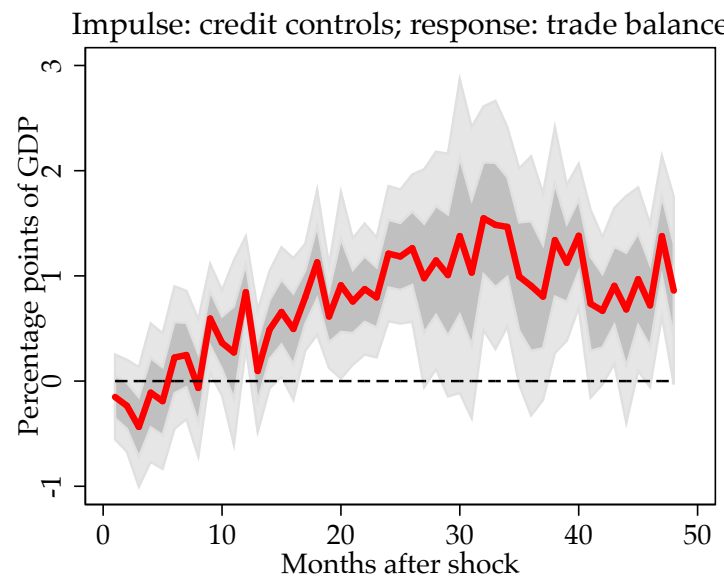

Notes: See text. 
and method (Figures $\mathrm{A}_{33}-\mathrm{A}_{40} \mathrm{O}$ and $\mathrm{A}_{49}-\mathrm{A}_{56}$ ), three discrepancies stand out. First, the magnitudes of the responses of lending, output and the trade balance are considerably larger in the period before September 1971. Second, the shape of the consumer price response is quite different in the post August 1971 period, although neither response is significant for long. Third - and most striking of all - when the sample is truncated to include only months with fresh forecasts (Figures A49-A56), the responses look quite different. These concerns are partly mitigated by the fact that the number of credit policy moves in this sample is only 18 , compared to 47 in the whole sample.

Given the potential importance of our finding that tighter credit controls do not reduce prices both to macroprudential policymakers today and to our understanding of the history of this period, we have subjected this result to extra scrutiny. One potential explanation is that the oil price shocks happened to occur soon after credit controls were imposed. If the rise in consumer prices was driven by the oil shock and credit controls did not cause the oil shock, then the rise in consumer prices we find would not represent a causal relationship. In fact, we can rule out this explanation by controlling for movements in the oil price for the months after the policy change. When we did this, the response of consumer prices to credit controls was broadly unchanged.

In sum, our results suggest that credit controls may have been useful to dampen output and improve the trade balance. However, it is far from clear that policymakers' trust in these instruments to curb inflation was warranted. But they did have strong, predictable, and intuitive effects on lending.

\section{Role of These Policies in UK Macroeconomic Developments}

In this section, we assess the contribution of exogenous changes in monetary and credit policy to the evolution of bank lending, output, and inflation during the 1960s and 1970s. Using the IRFs presented in Sections 5.2 and 5.3 enables us to estimate the contribution of the policy innovations described and presented in Section 5.1 above to key macroeconomic variables. At any given time, the contribution of policy to a given variable is the sum of the 
current and lagged policy innovations each multiplied by the elasticity of the variable to policy as represented by the relevant horizon of the IRF. In using this method, we assume that both policies were characterised by a stable reaction function over the period. This may not be a realistic assumption given the change in the monetary policy regime in the early 1970s; future work could take this structural break into account.

Figure 8 presents historical shock decompositions for the key macroeconomic variables in the model. The top two panels suggest that monetary and credit policy shocks were important drivers of bank lending and manufacturing output over the period. The effect of the credit policy relaxation that took place both ahead of and as part of the Competition and Credit Control reform is clearly visible in driving the lending boom in the early 1970s; the effect of tight monetary policy in driving the 1980 s recession is similarly apparent. The bottom panel suggests the pick-up in inflation in the 1970s was more than accounted for by monetary and credit policy shocks (i.e. the increase in the blue and green bars more than account for the rise in the red line). Interestingly, though, the contribution of credit policy to the rise in inflation stems from it becoming tighter, which may have represented a counterproductive attempt by policymakers to rein in inflation. This is consistent with Nelson and Nikolov's (2004) finding that the majority of the rise in UK inflation from the 1960 s to the 1970s was driven by "monetary policy neglect". 35

\section{Implications for Monetary and Macroprudential Policies Today}

Even though it is far from clear that credit policies were used successfully around the time of the Radcliffe Report, policymakers today might be able to learn from the experience. Central banks are now grappling with the challenges of a new mission, one that may require them to use unusual and controversial macroprudential tools alongside interest rate policy. There is an active debate about the efficacy of macroprudential tools and the appropriate role for monetary policy in securing financial stability (e.g., Korinek and Simsek, 2016; Stein, 2013; Svensson, 2015; and Williams, 2014).

\footnotetext{
35Batini and Nelson (2009) also argue that credit controls were mistakenly seen as a substitute for Bank Rate.
} 
Figure 8: Historical shock decomposition

The panels present our LP model-based estimates of the contribution of actual Bank Rate and credit control shocks to the actual annual percentage change in lending, output, and consumer prices.

(a) Bank lending

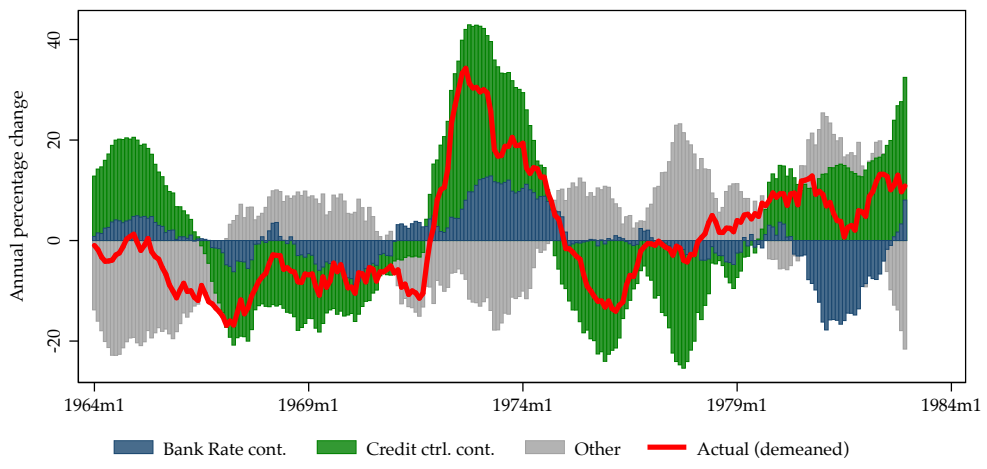

(b) Manufacturing output

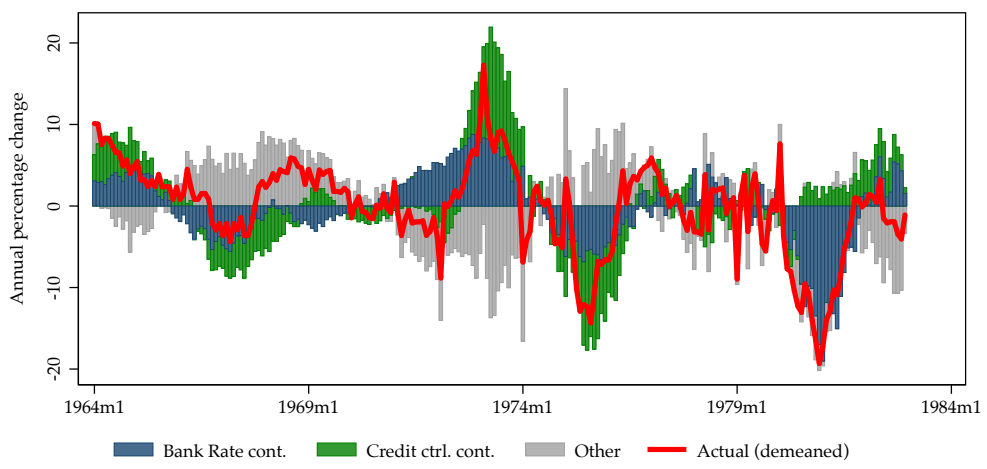

(c) Consumer prices

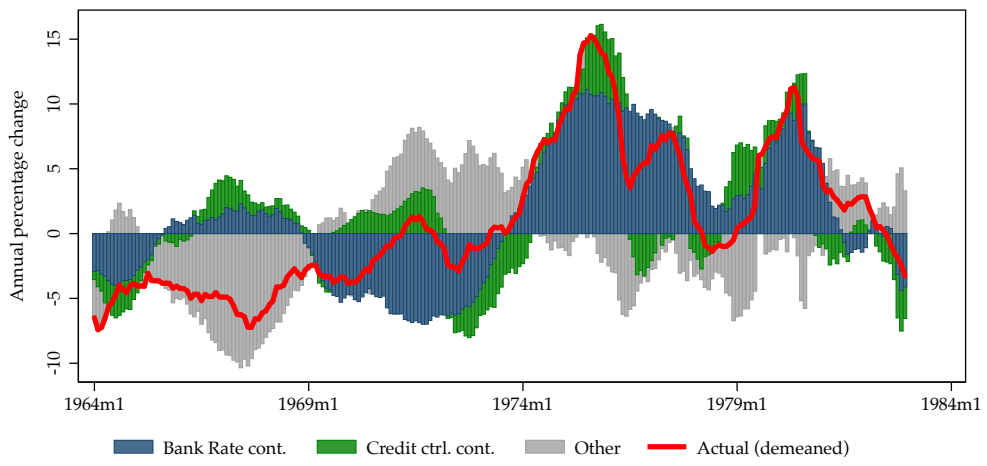

Notes: See text. 
Some of the macroprudential tools under consideration today are quite similar to the tools discussed in this paper. For example, liquidity regulations are similar to special and supplementary special deposits, while product tools such as loan-to-value regulations are similar to hire-purchase controls. And just as today, these tools were used alongside the policy rate, although today policymakers are seeking to achieve a different objective with macroprudential policy — namely, financial stability.

At this juncture, there is much uncertainty about how to measure systemic risk and hence the efficacy of macroprudential policy. Nevertheless, a number of authors have found that systemic banking crises are routinely preceded by deteriorations in non-financial private sector balance sheets (e.g., Schularick and Taylor, 2012) and Bush et al. (2015) find that bank balance sheets and indicators of risk appetite have also tended to signal crises. Given this, we investigate the effects of both monetary policy and credit policy on measures of bank balance sheets (the loan-to-deposit ratio of London Clearing Banks), non-financial balance sheets (the broad credit-to-GDP ratio), and risk appetite (the spread between debentures - medium-term corporate debt instruments - and gilts).

Figure 9 shows the results of this exercise. Following a tightening in either policy instrument, the loan-to-deposit ratio is estimated to decline and the debenture spread to rise. But whereas the credit-GDP ratio is estimated to decline persistently and considerably following a credit policy tightening, it is estimated to increase after a lag in response to a Bank Rate tightening, consistent with the fall in nominal GDP outweighing the fall in nominal lending.

Although these results are subject to the same caveats as above - and may be more vulnerable to the Lucas Critique, given credit policies were not used to limit systemic risk in the period we study - the findings suggest that credit policies may be better suited to financial stability goals than monetary policy. And coupled with the large uncertainty about their impact on output and particularly inflation, this points to directing macroprudential policy in the first instance at achieving financial stability aims, while directing monetary policy at achieving conventional inflation and output objectives. 
Figure 9: Impact of policies on financial stability risk indicators

The upper panels present the impact of contractionary Bank Rate and credit policy actions on the London clearing banks' aggregate loan to deposit ratio, an indicator of funding liquidity risk. The middle panels present the impact of these tools on the credit-GDP ratio, a commonly-used measure of the financial cycle. The bottom panel presents the tools' impact on the spread between debentures (medium-term corporate debt instruments) and gilts, a measure of risk appetite.

\section{(a) Bank Rate on loan to deposit ratio}

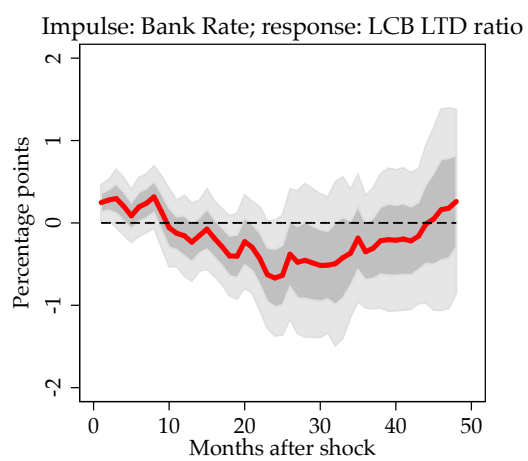

(c) Bank Rate on credit-GDP ratio

Impulse: Bank Rate; response: broad credit to GDP

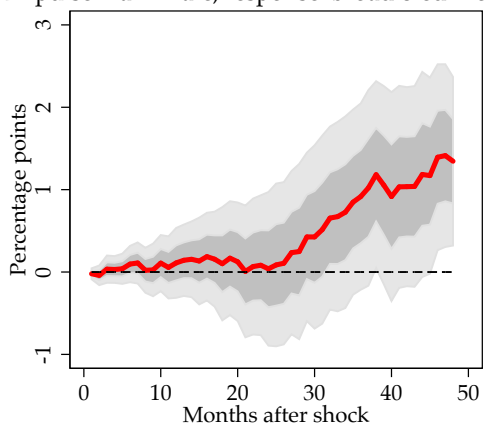

(e) Bank Rate on debenture spread

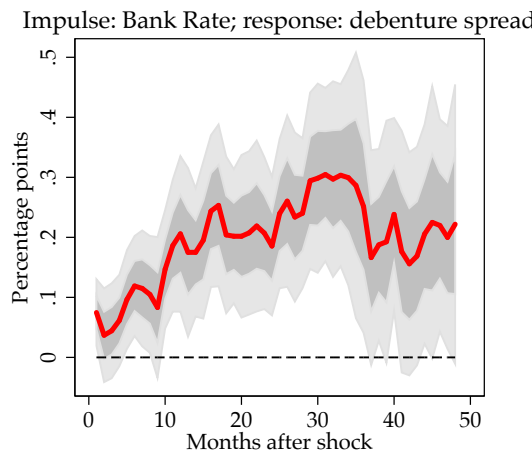

(b) Credit policy on loan to deposit ratio

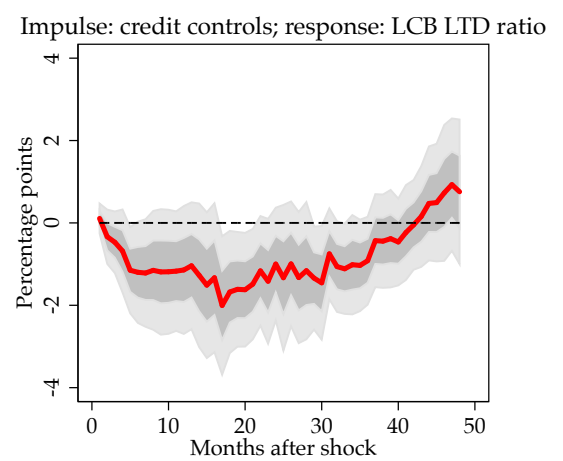

(d) Credit policy on credit-GDP ratio

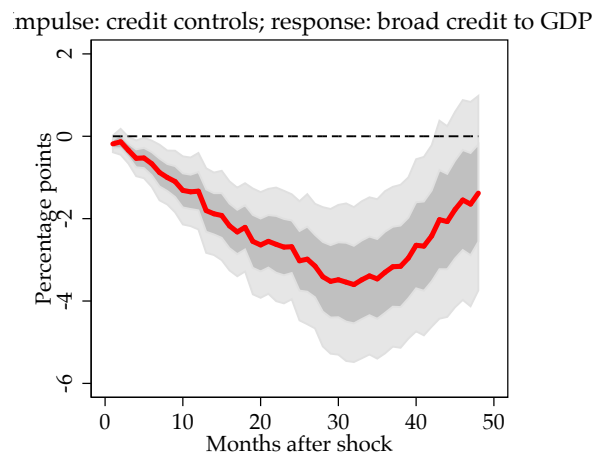

(f) Credit policy on debenture spread

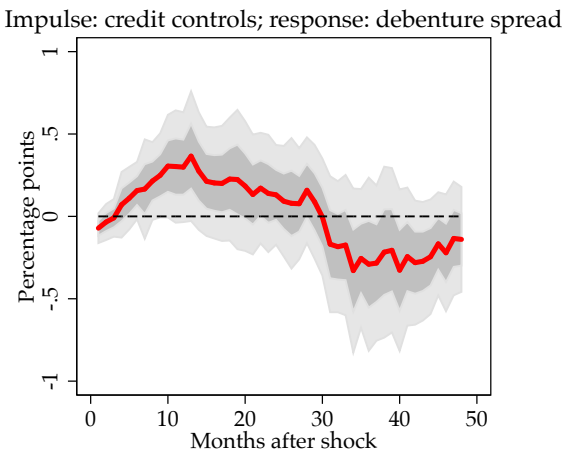

Notes: See text. 


\section{Conclusion}

In this paper, we use a novel econometric technique and a new dataset to study the effects of monetary and credit control policies on the macroeconomy in the United Kingdom between the 1960s and early 1980s.

We report three main results. First, we find that monetary and credit policies had qualitatively distinct effects on headline macroeconomic indicators during this period. Table 5a summarizes these differences. Increases in Bank Rate had robust negative effects on manufacturing output, and consumer prices especially, and positive effects on the trade balance. However, the estimated response of bank lending to an increase in Bank Rate is not statistically significant. By contrast, we find that credit controls - liquidity requirements on banks, credit growth limits, and constraints on the terms of consumer finance - had a strong negative impact on bank lending. We also find some evidence that credit policies may have depressed output, improved the trade balance, and led to an increase in consumer prices. But our evidence here is less strong than for corresponding shifts in Bank Rate. Overall, our estimates suggest that monetary and credit policies spanned different outcome spaces during this period. This result supports the notion that today's macroprudential tools, which are close cousins of the credit policies studied in this paper, might provide the additional independent tools required to help central banks meet both their monetary and financial stability objectives.

Second, we find that our estimated monetary and credit policy shocks were major drivers of macroeconomic dynamics over the 1960s and 1970s. A significant fraction of lending and output dynamics can be explained by these shocks. Moreover, we find that a large fraction of the pick-up in inflation in the 1970 can be attributed to expansionary monetary policy shocks - that is, interest rates were substantially looser in the latter part of our sample than would have been expected given available econonomic forecasts and the information about the state of the economy contained in our estimated factors.

Third, our impulse responses indicate that credit policies had moderating effects on

modern-day indicators of financial system vulnerabilities, while the effects of monetary 
Table 5: Summary of our results

(a) Impact of policies on macroeconomic indicators

\begin{tabular}{lcccc}
\hline \hline Policy & Credit & Output & Inflation & Trade Balance \\
\hline Bank Rate & $\downarrow$ & $\downarrow$ & $\downarrow \downarrow$ & $\uparrow$ \\
Credit Policy & $\downarrow \downarrow$ & $\downarrow$ & $\uparrow$ & $\uparrow$ \\
\hline \hline
\end{tabular}

(b) Impact of policies on financial stability indicators

\begin{tabular}{lccc}
\hline \hline Policy & Loan-to-deposit ratio & Credit-to-GDP ratio & Debenture spread \\
\hline Bank Rate & $\downarrow$ & $\uparrow$ & $\uparrow$ \\
Credit Policy & $\downarrow$ & $\downarrow \downarrow$ & $\uparrow$ \\
\hline \hline
\end{tabular}

policy actions were less clear cut. Table $5 \mathrm{~b}$ summarizes these findings. Contractionary credit policies had large and persistent negative effects on the credit-to-GDP ratio; they also reduced banks' loan to deposit ratios (a measure of their resilience), and increased the spread between debentures i.e. term corporate debt instruments and gilts (a measure of investor risk appetite). In contrast, we find that contractionary monetary policy led to a persistent increase in the credit-to-GDP ratio, as the fall in GDP exceeded the fall in credit. Contractionary monetary policy actions also led to a small reduction in banks' loan-to-deposit ratios, but led to a large persistent increase in the debenture spread. Our results therefore provide some support to the view that macroprudential policy is better suited to achieving financial stability goals than monetary policy. 


\section{REFERENCES}

Allard, R (1974), 'An Economic Analysis of the Effects of Regulating Hire-Purchase', Government Economic Service Occasional Paper, No. 9.

Allen G, Goulding, L and O'Donoghue, J (2004), 'Consumer Price Inflation since 1750', Economic Trends, No. 604.

Bank of England (1960), 'Commentary', Bank of England Quarterly Bulletin, Vol. 1. No. 1, pages 3-17.

Bank of England (1962a), 'Bank liquidity in the United Kingdom', Bank of England Quarterly Bulletin, Vol. 2. No. 4, pages 248-255.

Bank of England (1962b), 'Sources of funds of hire purchase companies 1958-62', Bank of England Quarterly Bulletin, Vol. 2. No. 4, pages 256-262.

Bank of England (1969), 'The operation of monetary policy since the Radcliffe Report', Bank of England Quarterly Bulletin, Vol. 9, No. 4, pages 448-460.

Bank of England (1982), 'The supplementary special deposits scheme', Bank of England Quarterly Bulletin, Vol. 22, No. 1, pages 74-85.

Bank of England (2009), 'The role of macroprudential policy', Bank of England Discussion Paper, November.

Batini, N and Nelson, E (2009), The UK's rocky road to stability, New York: Nova Science Publishers.

Bernanke, B, and Boivin, J (2003), 'Monetary policy in a data-rich environment', Journal of Monetary Economics, Vol. 50, No. 3, pages 525-546.

Bernanke, B, Boivin, J and Eliasz, P (2005), 'Measuring the Effects of Monetary Policy: A Factor Augmented Vector Autoregressive (FAVAR) approach', Quarterly Journal of Economics, Vol. 120, No. 1, pages 387-422.

Bush, O, Guimaraes, R and Stremmel, H (2015), 'Beyond the credit gap: price and quantity of risk indicators for macroprudential policy', mimeo.

Capie, F (2010), The Bank of England: 1950s to 1979, Cambridge: Cambridge University Press.

Capie, F and Webber, A (1985), A Monetary History of the United Kingdom, 1870-1982, Volume 1, London: Allen and Unwin, 1985.

Cloyne, J and Hürtgen, P (2014), 'The macroeconomics effects of monetary policy: a new measure for the United Kingdom', Bank of England Working Paper, No. 493.

Cochrane, J (2004), 'Comments on "A new measure of monetary shocks: Derivation and implications" by Christina Romer and David Romer', http://gsbwww.uchicago.edu/fac/john.cochrane/research/.

Cochrane, J (2013), 'The Danger of an All-Powerful Federal Reserve', The Wall Street Journal, 26 August.

Coibion, O (2012), 'Are the Effects of Monetary Policy Shocks Big or Small?', American Economic Journal: Macroeconomics, Vol. 4, No. 2, pages 1-32.

Committee on the Working of the Monetary System (1959), Report, London: HM Stationery Office.

Crockett, A (2000), 'Marrying the micro-and macro-prudential dimensions of financial stability', BIS speeches, No. 21.

Dean, A (1976), 'Errors in National Institute Forecasts of personal incomes, inflation and employment, 1965-75', National Institute Economic Review, No. 78, pages 48-57.

Economist (2014), 'Choosing the right pin', 30 August. 
Elliott, D, Feldberg, G and Lehnert, A (2013), 'The History of Cyclical Macroprudential Policy in the United States', Finance and Economics Discussion Series, Federal Reserve Board, No. 29.

Ellis, C, Mumtaz, H and Zabczyk, P (2014), 'What Lies Beneath? A Time-varying FAVAR Model for the UK Transmission Mechanism', The Economic Journal, Vol. 124, pages 668-699.

Fforde, J (1992), The Bank of England and public policy, 1941-1958, Cambridge University Press, Cambridge.

Fischer, S (2014), 'Financial Sector Reform: How Far Are We?', Martin Feldstein Lecture, National Bureau of Economic Research, Cambridge, Massachusetts, 10 July.

Fischer, S (2015), 'Macroprudential Policy in the U.S. Economy', Speech at "Macroprudential Monetary Policy," the 59th Economic Conference of the Federal Reserve Bank of Boston, Boston, Massachusetts, 2 October.

Glocker, C and Towbin, P (2012), 'Reserve Requirements for Price and Financial Stability: When Are They Effective?', International Journal of Central Banking, Vol. 8, No. 1, pages 65-113.

Goodhart, C (2014), 'Competition and Credit Control', Financial Markets Group Special Paper, No. 229.

Hills, S, Thomas, R and Dimsdale, N (2015), 'Three Centuries of Data — Version 2.2', www.bankofengland.co.uk. Hodgman, D (1971), 'British techniques of monetary policy: A critical review', Journal of Money, Credit and Banking, Vol. 3, No. 4, pages 760-779.

Jordà, Ò (2005), 'Estimation and Inference of Impulse Responses by Local Projections', American Economic Review, Vol. 95, No. 1, pages 161-182.

Kennedy, M (1969), 'How well does the National Institute Forecast?', National Institute Economic Review, No. 50, pages 40-52.

Kennedy, S (2014), 'We're All Macroprudentialists Now as Bubble Policy Dawns', Bloomberg Business, 17 June.

Korinek, A and Simsek, A (2016), 'Liquidity Trap and Excessive Leverage', American Economic Review, Vol. 106, No. 3, pages 699-738.

Major, R and Surrey, M (1970), 'Errors in National Institute Forecasts of the Balance of Payments', National Institute Economic Review, No. 52, pages 35-45.

Miller, M (1973), 'Discussion', in Allocation Techniques and Monetary Policy, pages 137-61, Boston: Federal Reserve Bank of Boston.

Milne, R (2014), 'Central banks: Stockholm syndrome', Financial Times, 19 November.

Monnet, E (2012), 'Monetary Policy without Interest Rates: Evidence from France's Golden Age (1948 to 1973) Using a Narrative Approach', European Historical Economics Society Working Paper, No. 32.

Monnet, E (2014a), 'Monetary Policy without Interest Rates: Evidence from France's Golden Age (1948 to 1973) Using a Narrative Approach', American Economic Journal: Macroeconomics, Vol. 6, No. 4, pages 137-169.

Monnet, E (2014b), 'The diversity in national monetary and credit policies in Western Europe under Bretton Woods', in Central banks and the nation states, Feiertag, O and Margairaz, M (eds), Paris, Sciences Po, forthcoming.

Needham, D (2015), 'Britains Money Supply Experiment, 1971-73', The English Historical Review, Vol. 130, No. 542, pages 89-122.

Nelson, E and Nikolov, K (2004), 'Monetary Policy and Stagflation in the UK', Journal of Money, Credit, and Banking, Vol. 36, No. 3, pages 293-318. 
Nield, R and Shirley, E (1961), 'Economic Review - An Assessment of Forecasts, 1959-60', National Institute Economic Review, No. 15, pages 12-29.

Ramey, V (2016), 'Macroeconomic Shocks and Their Propagation', NBER Working Paper, No. 21978. Romer, C and Romer, D (1993), 'Credit channel or credit actions? An interpretation of the postwar transmission mechanism', in Changing Capital Markets: Implications for Monetary Policy. A symposium sponsored by the Federal Reserve Bank of Kansas City, pages 71-116.

Romer, C and Romer, D (2004), 'A New Measure of Monetary Shocks: Derivation and Implications', American Economic Review, Vol. 94, No. 4, pages 1055-1084.

Romer, C and Romer, D (2013), 'The Most Dangerous Idea in Federal Reserve History: Monetary Policy Doesn't Matter', American Economic Review, Vol. 103, No. 3, pages 55-6o.

Schularick, M and Taylor, A (2012), 'Credit Booms Gone Bust: Monetary Policy, Leverage Cycles, and Financial Crises, 1870-2008', American Economic Review, Vol. 102, No. 2, pages 1029-61.

Schwartz, A (1969), 'Why Money Matters', Lloyds Bank Review, No. 24, pages 1-16.

Stein, J (2013), 'Overheating in the credit markets: origins, measurement and policy responses', speech given at the 'Restoring Household Financial Stability after the Great Recession: Why Household Balance Sheets Matter' research symposium sponsored by the Federal Reserve Bank of St. Louis, St. Louis, Missouri.

Stock, J and Watson, M (2002), 'Macroeconomic forecasting using diffusion indexes', Journal of Business \& Economic Statistics, Vol. 20, No. 2, pages 147-162.

Svensson, L (2015), 'Monetary policy and macroprudential policy: different and separate', mimeo.

Tarullo, D (2013), 'Macroprudential Regulation', speech at the Yale Law School Conference on Challenges in Global Financial Services, New Haven, CT., 20 September.

Williams, J (2014), 'Financial stability and monetary policy: happy marriage or untenable union?', FRBSF Economic Letter, No. 17.

Zdzienicka, A, Chen, S, Kalan, F, Laseen, S and Svirydzenka, K (2015), 'Effects of Monetary and Macroprudential Policies on Financial Conditions : Evidence from the United States', IMF Working Paper, No. 15/288. 


\section{Appendix 1: National Institute Forecast Evaluations}

This appendix contains quotes from a series for forecast evaluation exercises in the National Institute Economic Review. In summary, the Institute seems to have taken forecasting seriously and its forecasts were comparable in quality to other leading forecasters.

Within two years the Institute assessed its forecast (Nield and Shirley, 1961), finding that:

“The Review, since it appears fairly frequently and has attempted always to take a view of the future, was probably a significant factor [in the similarity between different forecasts, including HM Treasury's]"

"Our forecasts compare quite favourably with those made by others. But none was very good"

In 1969, NIESR commissioned an independent academic to evaluate its forecasts (Kennedy, 1969), finding that:

"The forecasts have done extremely well as qualitative indicators of the rate of economic expansion"

"The main conclusion from this comparison is that there is no startling difference in the degree of accuracy achieved by the National Institute's forecasts, on the one hand, and the more formal, econometric model on the other"

"One reason for investigating the value of the forecasts from the point of view of economic policy is that the forecasts are used as a basis for the policy recommendations presented in the National Institute Economic Review, and these wield some influence on public opinion"

"A second, and more important point, [sic] is that the mean absolute forecast error for GDP is, at 1.4 per cent, rather large in policy terms"

Next year, the Institute focused on the balance of payments forecast (Major and Surrey, 1970), finding that:

"Over the last seven years the errors made in February in predicting annual changes in the current balance have been even bigger. At an average of over $£ 250$ million a year they have been virtually as big as the variations in the changes themselves and about as large as the errors which would have resulted if the forecast each year had been 'no change'"

“The February forecasts at least still compare very favourably with those published by other bodies at about the same time.... This, however, merely underlines the difficulty of producing balance of payments forecasts which will give more than a weak basis for policy recommendations or decisions"

The year 1976 was the first time that the Review focussed on forecast errors for inflation (Dean, 1976), finding that: 
"The most serious error made in the various National Institute forecasts of personal incomes and prices has been the tendency to underestimate inflation. This error has been less serious for the consumer price index than for the other current prices variables studies. It was suggested above that this may be because the cost mark-up approach adopted for forecasting prices involves the use of lagged variables, some of which are already known at the time of the forecast"

"Apart from other personal incomes and total personal disposable incomes the National Institute forecasts generally outperform the three naïve models tested"

\section{Appendix 2: Monthly DAtaset}

Table Ai shows the 67 variables in our monthly dataset. Variables were seasonally adjusted and transformed where appropriate. The second column below shows the transformation, with ' 1 ' indicating no transformation and ' 2 ' indicating that the log difference was taken.

Table A1: Variables used in estimating factors

\begin{tabular}{|c|c|c|c|c|c|}
\hline \multicolumn{3}{|c|}{ Domestic demand and output } & \multicolumn{3}{|c|}{ Financial markets (cont.) } \\
\hline 1 & 2 & Index of production & 35 & 1 & Call rate \\
\hline 2 & 2 & Mining and quarrying output & 36 & 1 & Bank deposit rate \\
\hline 3 & 2 & Manufacturing output & 37 & 1 & Trade bill rate \\
\hline 4 & 2 & Food, drink and tobacco output & 38 & 1 & Bank bill rate \\
\hline 5 & 2 & Textiles output & 39 & 1 & Debenture yield \\
\hline 6 & 2 & Chemicals output & 40 & 2 & Gold price \\
\hline 7 & 2 & Metals output & 41 & 2 & Oil price \\
\hline 8 & 2 & Engineering output & 42 & 2 & Commodity prices \\
\hline 9 & 2 & Other manufacturing output & & & \\
\hline 10 & 2 & Gas, water and electricity output & \multicolumn{3}{|c|}{ Money, credit and banking } \\
\hline 11 & 1 & Number of days lost to industrial stoppages & 43 & 2 & Mo \\
\hline 12 & 2 & Retail sales volume & 44 & 2 & M2 \\
\hline 13 & 2 & Retail durables value & 45 & 2 & Bank lending \\
\hline 14 & 2 & Number of dwellings started & 46 & 2 & London Clearing Bank (LCB) claims on BoE \\
\hline \multirow[t]{2}{*}{15} & 2 & Number of new vehicle registrations & 47 & 2 & LCB deposits \\
\hline & & & 48 & 2 & LCB advances \\
\hline \multicolumn{3}{|c|}{ Labour market } & 49 & 2 & LCB investments \\
\hline 16 & 2 & Manufacturing employment & 50 & 1 & LCB excess liquid assets / deposits \\
\hline 17 & 2 & Other employment in the industrial sector & & & \\
\hline 18 & 1 & Vacancies & \multicolumn{3}{|c|}{ Prices } \\
\hline 19 & 1 & Unemployment rate & 51 & 2 & Import prices \\
\hline 20 & 2 & Economy-wide hours & 52 & 1 & Terms of trade \\
\hline \multirow[t]{2}{*}{21} & \multirow[t]{2}{*}{2} & \multirow[t]{2}{*}{ Manufacturing hours } & 53 & 2 & Producer input prices \\
\hline & & & 54 & 2 & Producer output prices \\
\hline \multicolumn{3}{|c|}{ Trade and reserves } & 55 & 2 & Economy-wide average wages \\
\hline 22 & 2 & Goods export volume & 56 & 2 & Manufacturing average wages \\
\hline 23 & 2 & Goods import volume & 57 & 2 & Consumer prices \\
\hline 24 & 1 & Trade balance to GDP ratio & & & \\
\hline 25 & 2 & FX reserve to GDP ratio & \multicolumn{3}{|c|}{ Foreign variables } \\
\hline & & & 58 & 2 & US industrial production \\
\hline \multicolumn{3}{|c|}{ Financial markets } & 59 & 2 & US consumer prices \\
\hline 26 & 2 & $£$ per $\$$ & 60 & 1 & US Treasury bill yield \\
\hline 27 & 2 & FFr per $\$$ & 61 & 1 & US long-term bond yield \\
\hline 28 & 2 & DM per \$ & 62 & 2 & German industrial production \\
\hline 29 & 1 & Dollar forward margin & 63 & 2 & German consumer prices \\
\hline 30 & 2 & Stock prices & 64 & 1 & German short-term interest rate \\
\hline 31 & 1 & Dividend yield & 65 & 2 & French industrial production \\
\hline 32 & 1 & Treasury bill yield & 66 & 2 & French consumer prices \\
\hline 33 & 1 & 10-year gilt yield & 67 & 1 & French short-term interest rate \\
\hline 34 & 1 & Consol yield & & & \\
\hline
\end{tabular}




\section{Supplementary Appendix: Robustness}

\section{Exhibit A1: Robustness to different factor combinations: Bank Rate}

Each of these panels shows the range of central estimates as we varied the number of factors and lags from three factors with one lag to seven factors with two lags.

Chart Aı: Bank lending

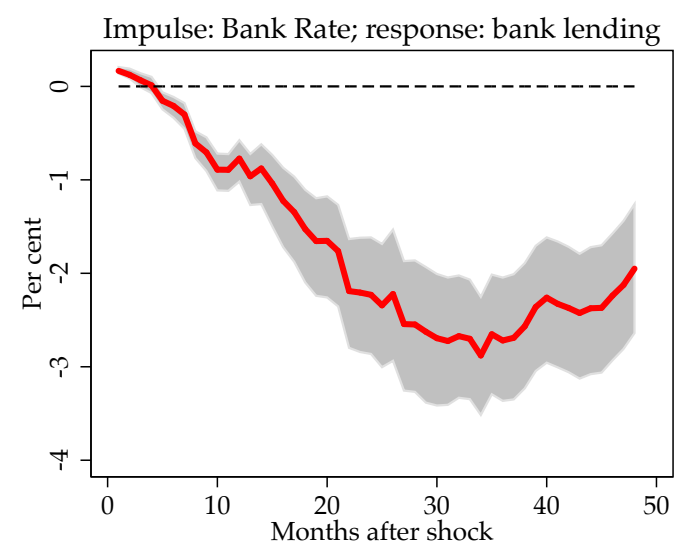

Chart A3: Consumer prices

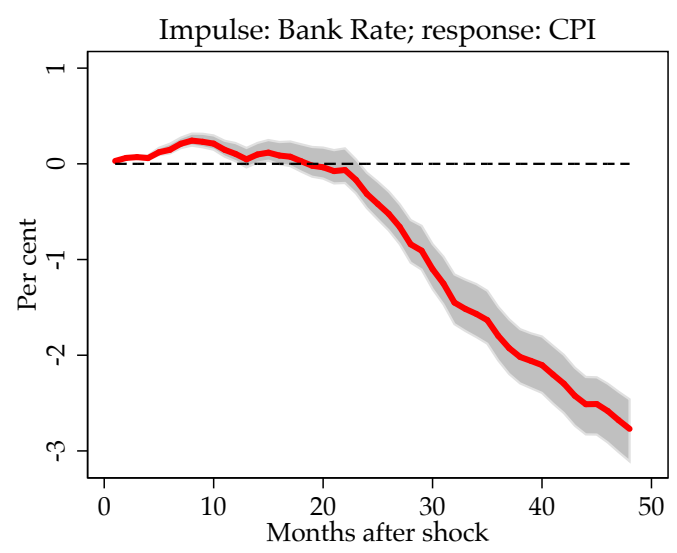

Chart A2: Manufacturing output

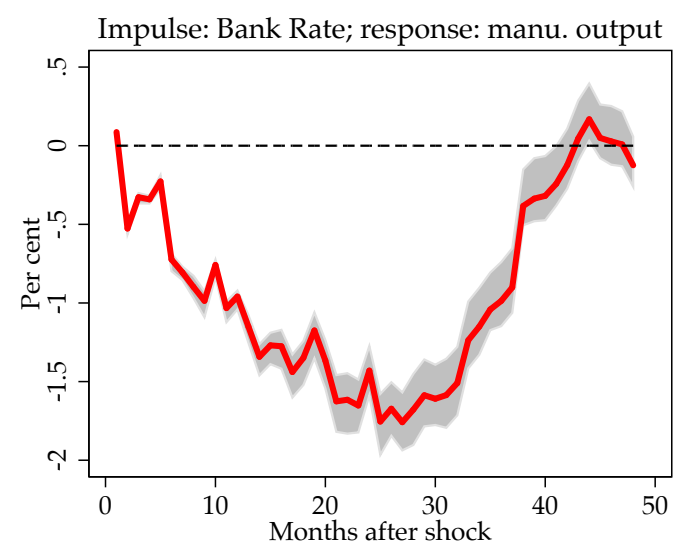

Chart A4: Trade balance

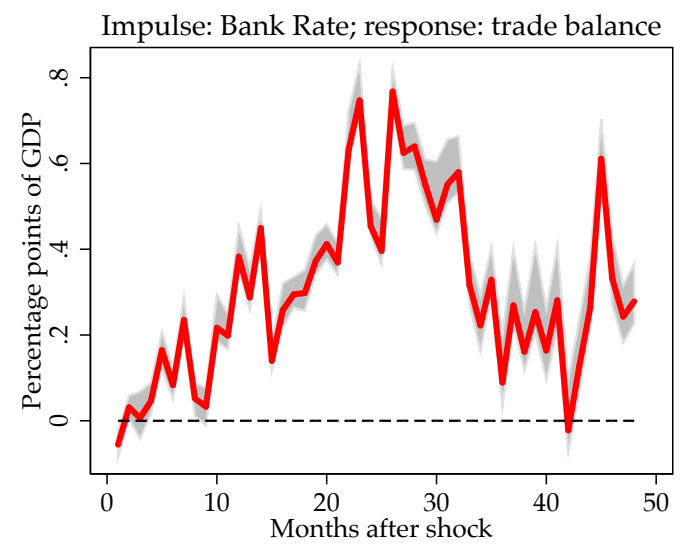




\section{Exhibit A2: Robustness to different factor combinations: Credit controls}

Each of these panels shows the range of central estimates as we varied the number of factors and lags from three factors with one lag to seven factors with two lags.

Chart A5: Bank lending

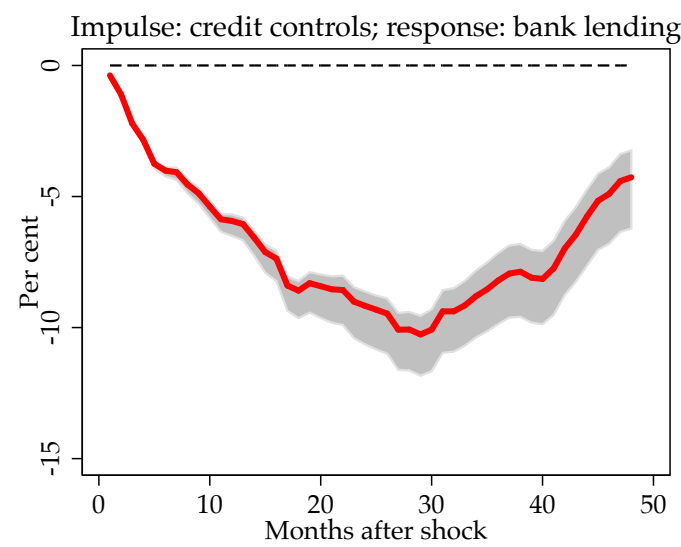

Chart A7: Consumer prices

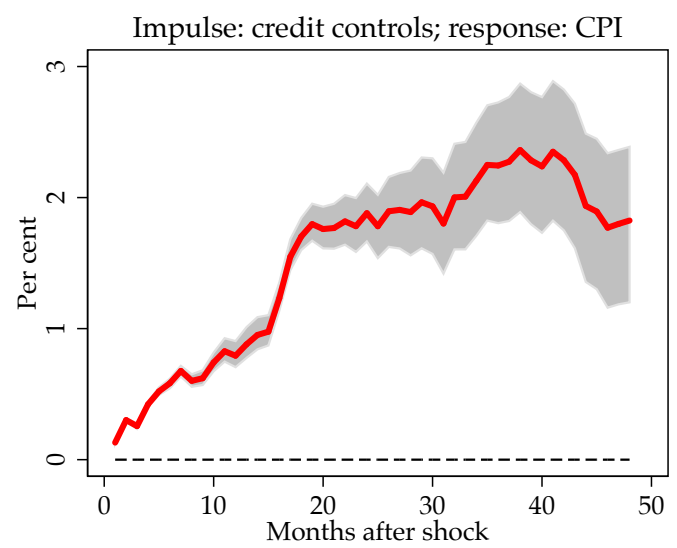

Chart A6: Manufacturing output

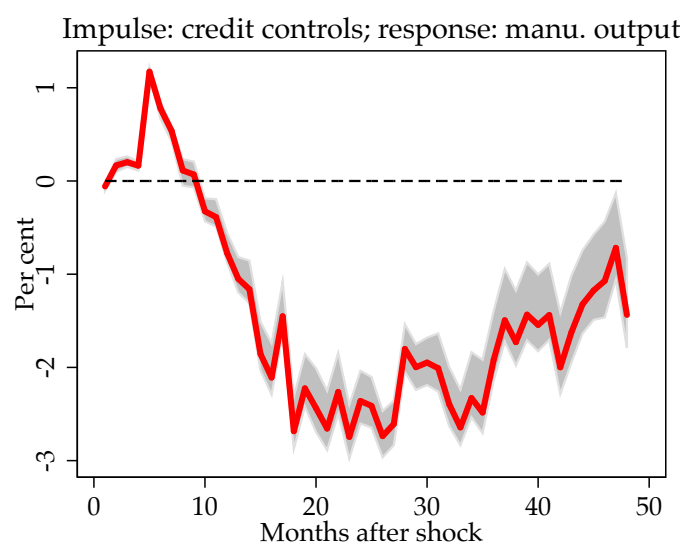

Chart A8: Trade balance

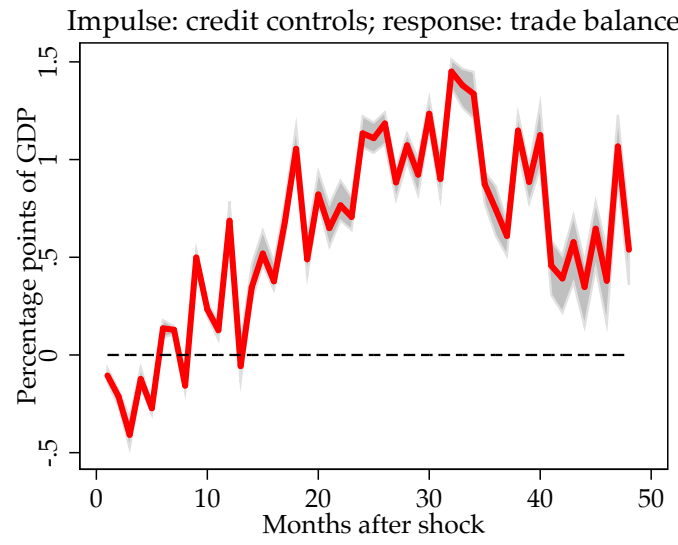




\section{Exhibit A3: Robustness to different time periods: Bank Rate}

These panels show the results for policy shocks before September 1971 (Competition and Credit Control) and after August 1971 (the Nixon shock). The full sample was used for these estimates with policy variables split into two series ('before' and 'after').

Chart A9: Bank lending, pre 09/71

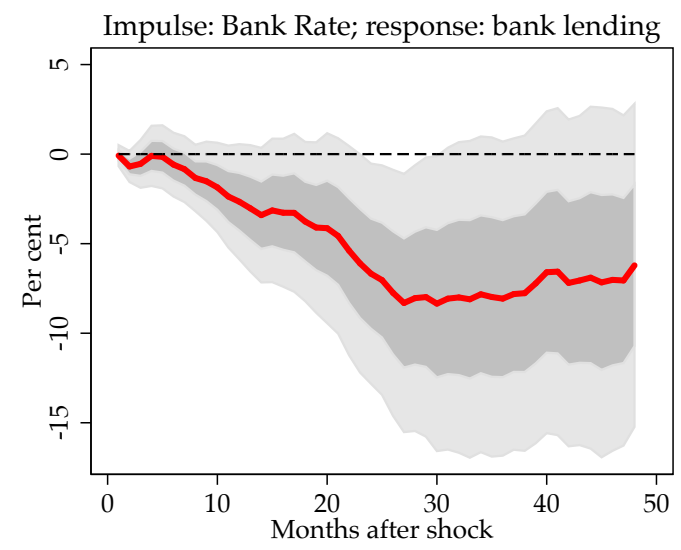

Chart A11: Manufacturing output, pre $09 / 71$

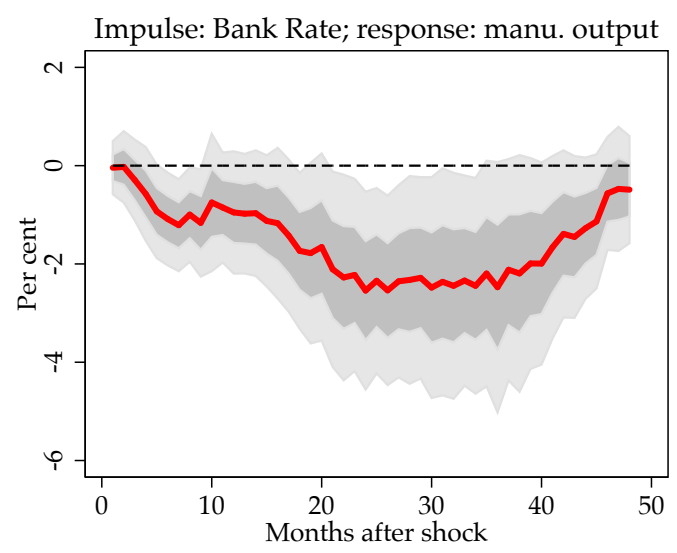

Chart A10: Bank lending, post o8/71

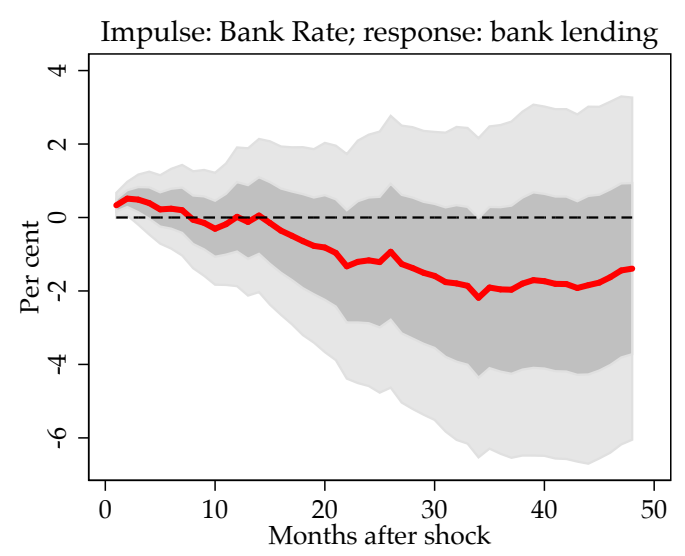

Chart A12: Manufacturing output, post $08 / 71$

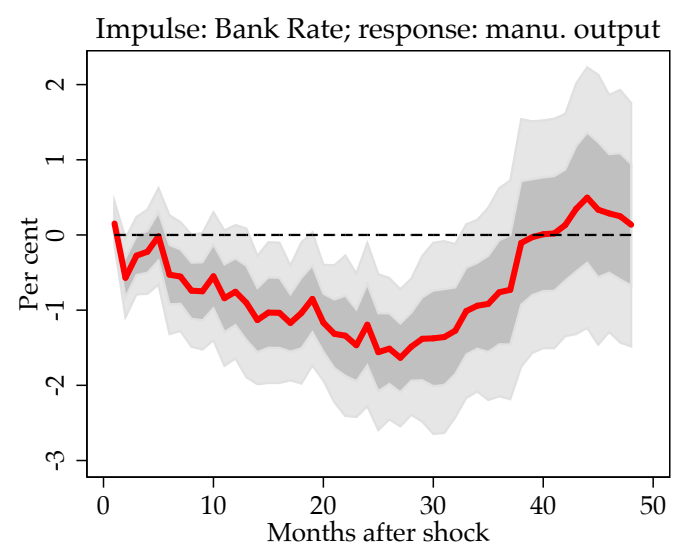


Chart A13: Consumer prices, pre 09/71

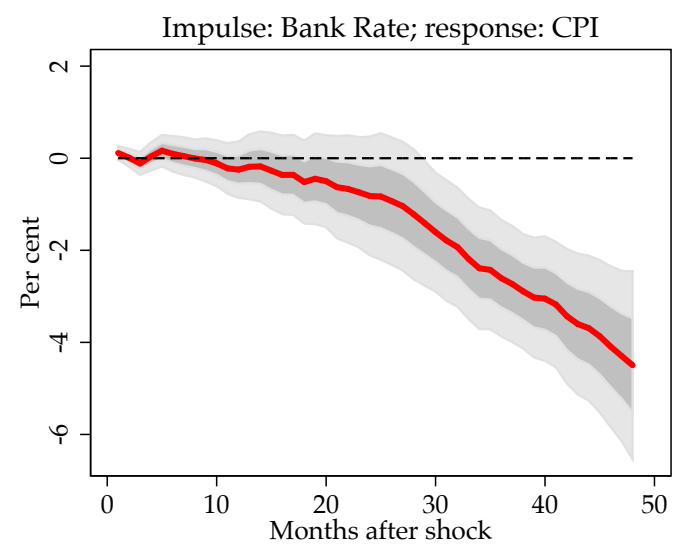

Chart A15: Trade balance, pre 09/71

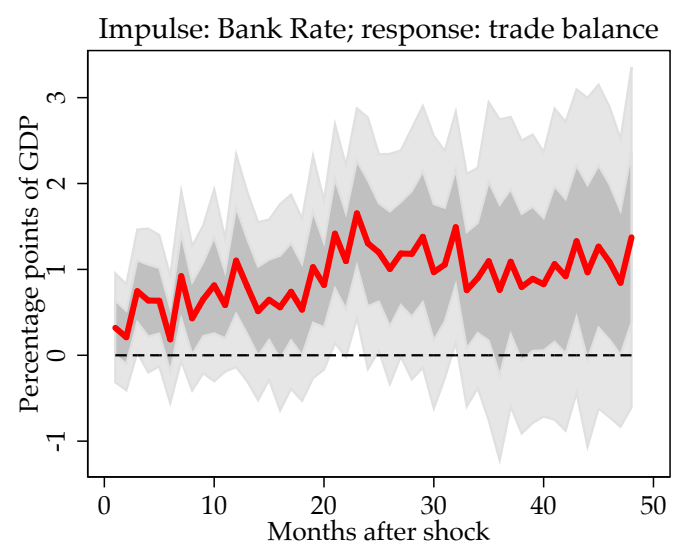

Chart A14: Consumer prices, post 08/71

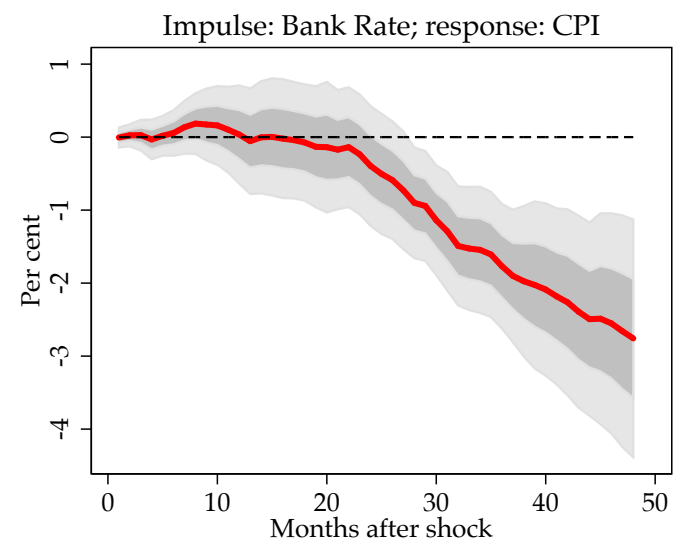

Chart A16: Trade balance, post $08 / 71$

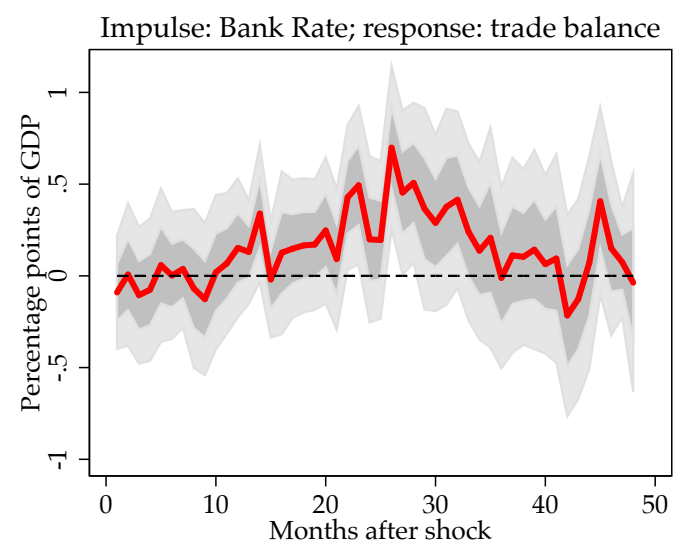




\section{Exhibit A4: Robustness to different time periods: Credit controls}

These panels show the results for policy shocks before September 1971 (Competition and Credit Control) and after August 1971 (the Nixon shock). The full sample was used for these estimates with policy variables split into two series ('before' and 'after').

Chart A17: Bank lending, pre 09/71

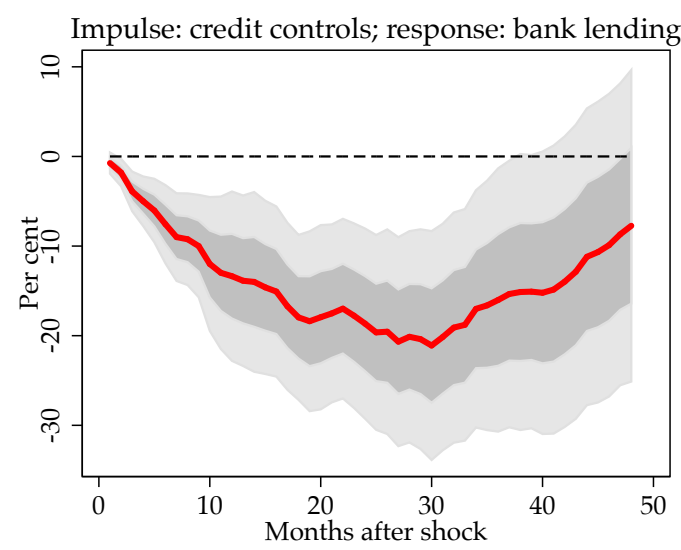

Chart A19: Manufacturing output, pre $09 / 71$

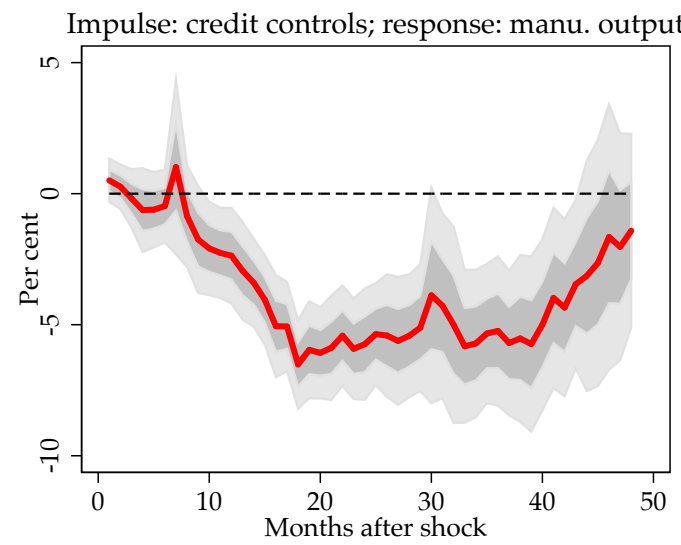

Chart A18: Bank lending, post 08/71

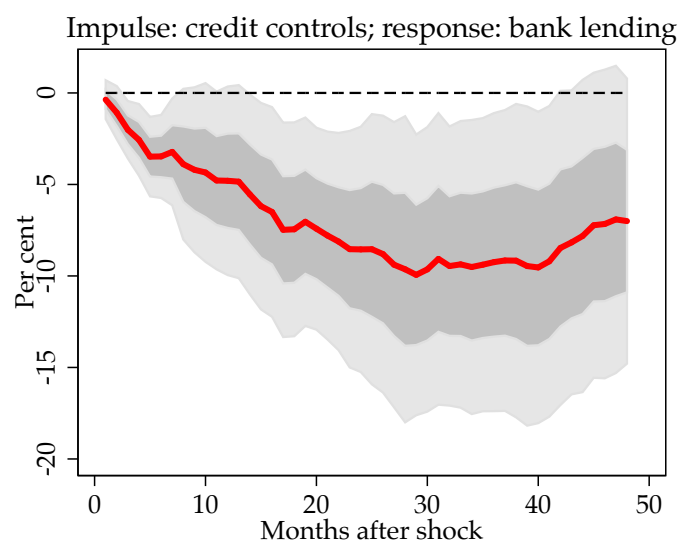

Chart A20: Manufacturing output, post $08 / 71$

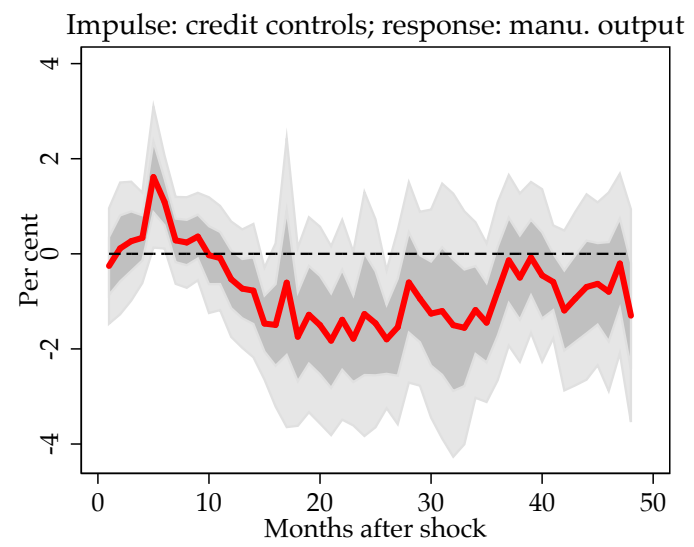


Chart A21: Consumer prices, pre 09/71

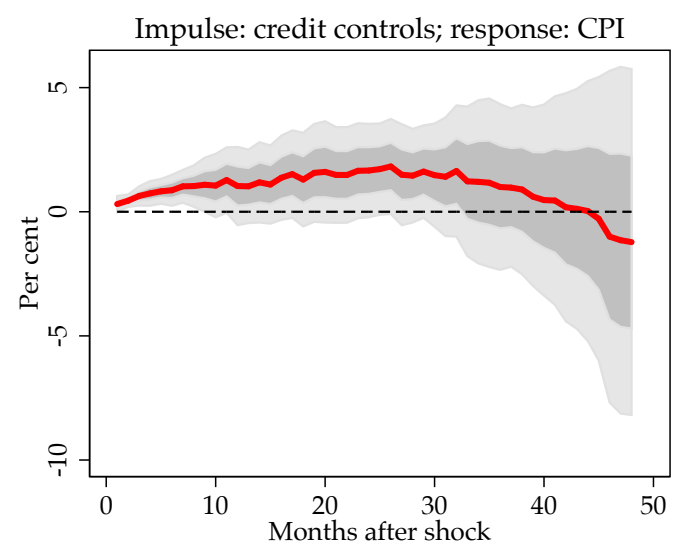

Chart A23: Trade balance, pre 09/71

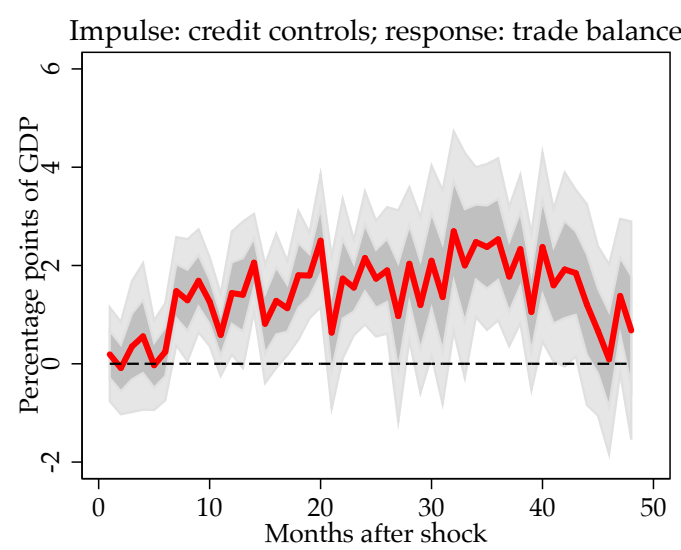

Chart A22: Consumer prices, post 08/71

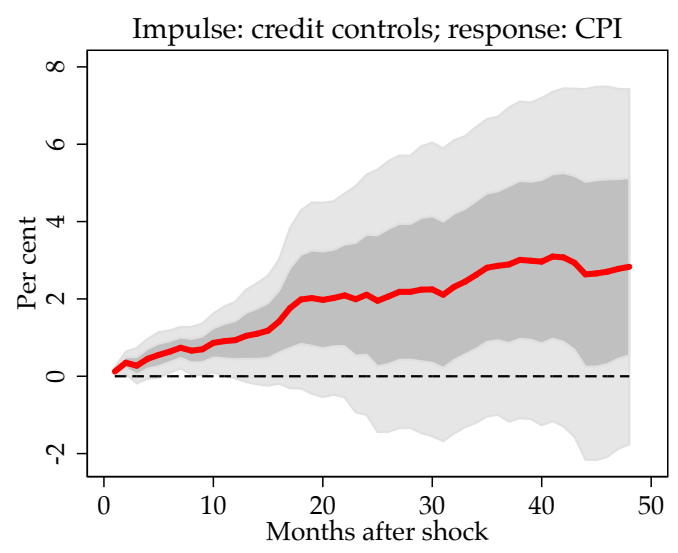

Chart A24: Trade balance, post o8/71

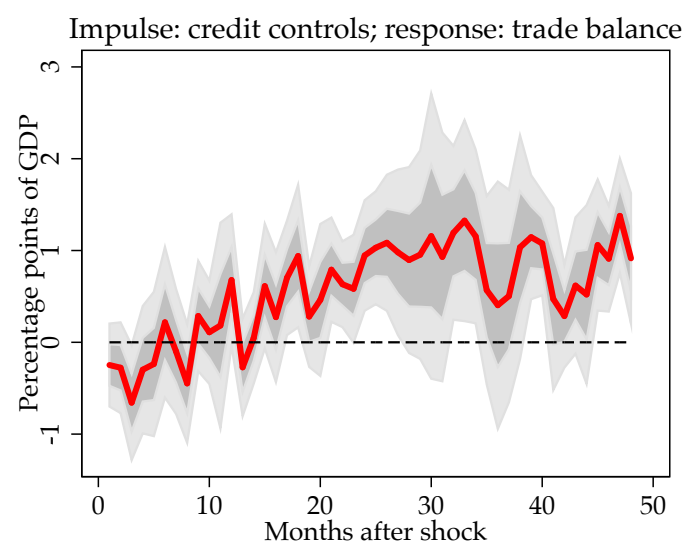




\section{Exhibit A5: Comparison with factor-only approach: Bank Rate}

These panels compare our baseline results, estimated using forecasts and factors, in the left-hand column and results omitting forecasts in the right-hand column.

Chart A25: Bank lending, baseline

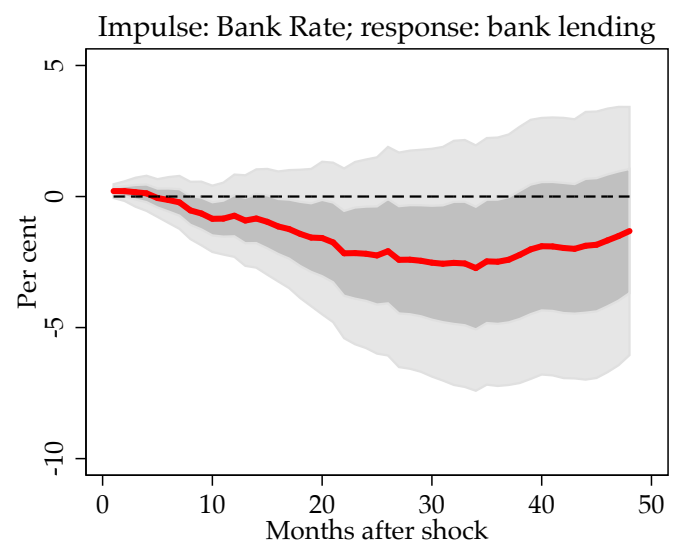

Chart A27: Manufacturing output, baseline

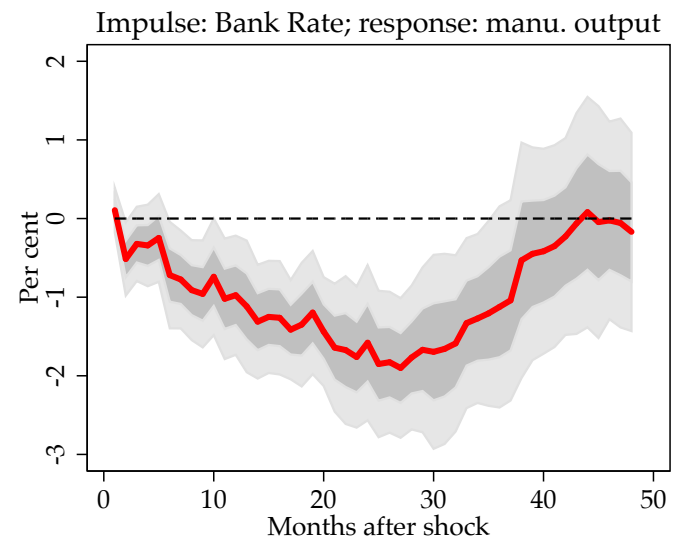

Chart A26: Bank lending, factor-only

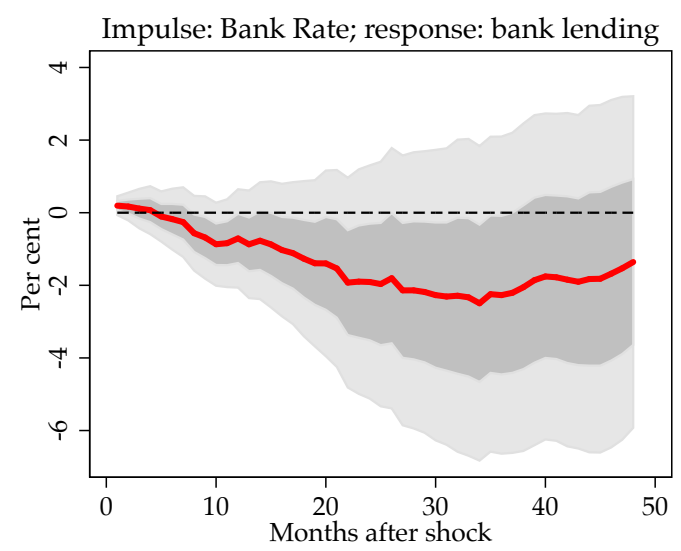

Chart A28: Manufacturing output, factoronly

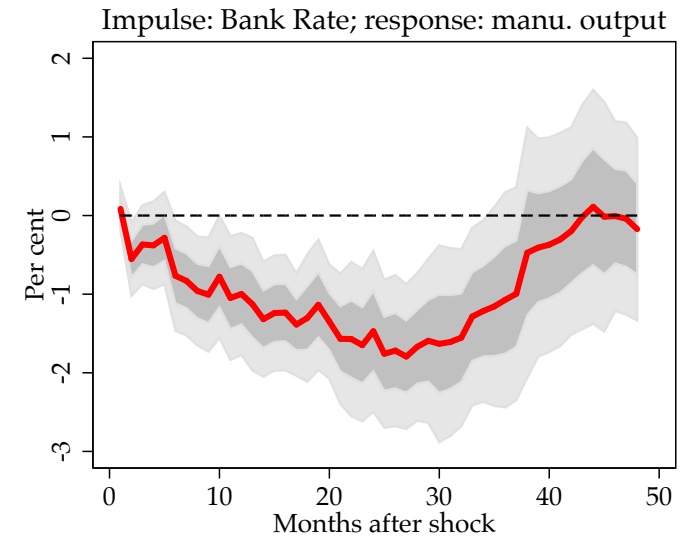


Chart A29: Consumer prices, baseline

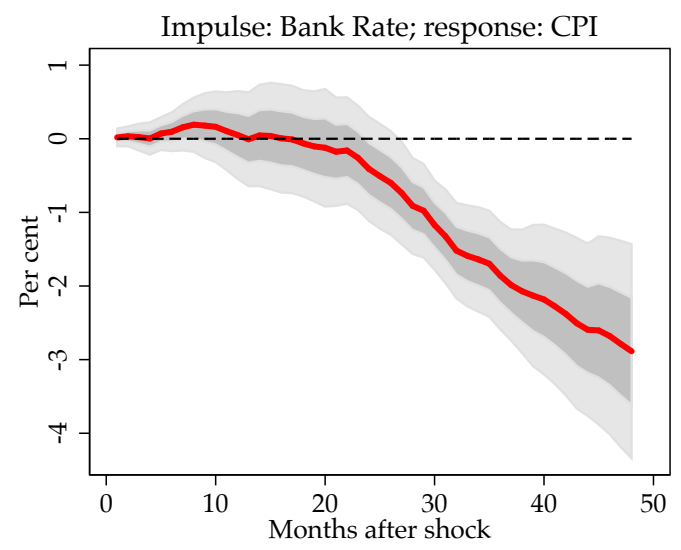

Chart A31: Trade balance, baseline

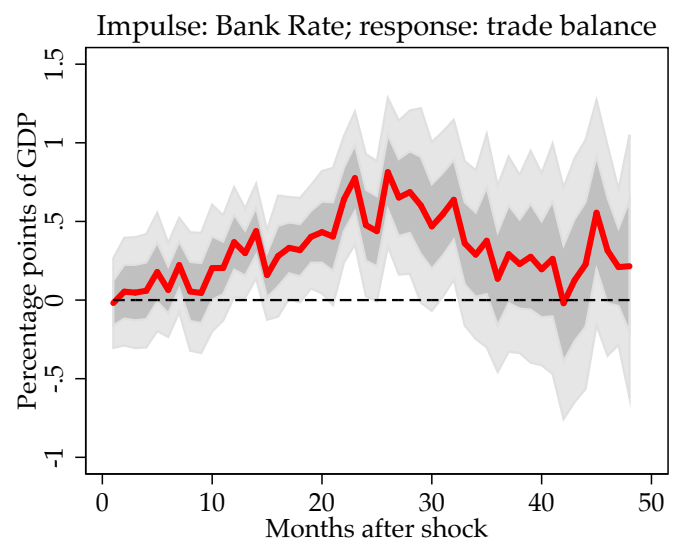

Chart A30: Consumer prices, factor-only

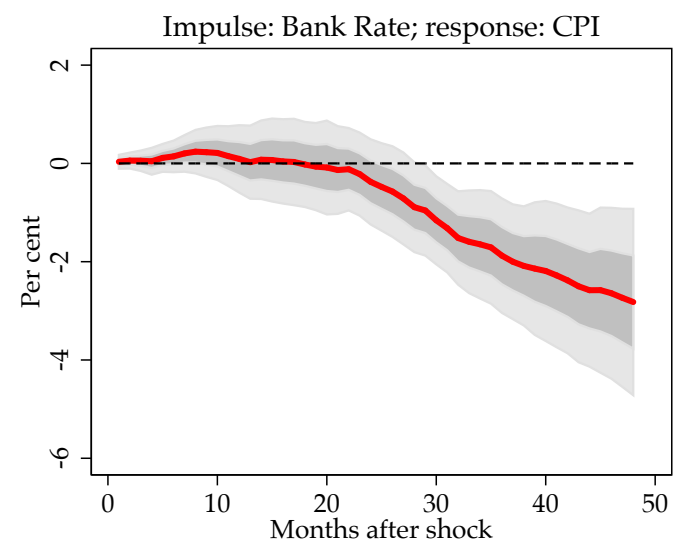

Chart A32: Trade balance, factor-only

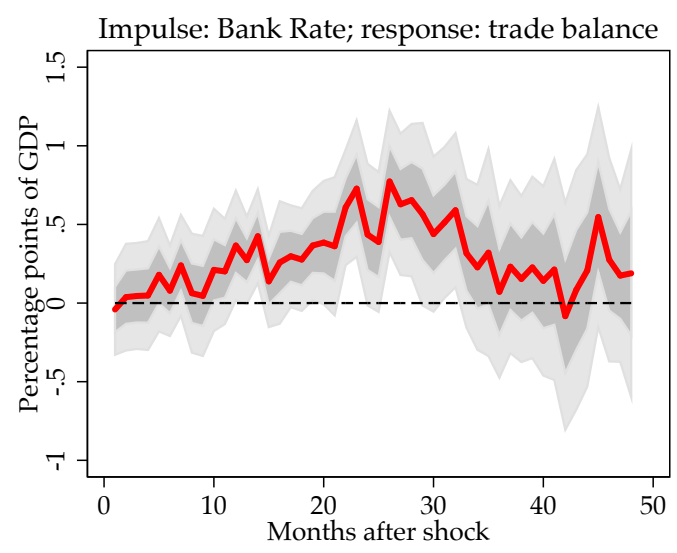




\section{Exhibit A6: Comparison with factor-only approach: Credit controls}

These panels compare our baseline results, estimated using forecasts and factors, in the left-hand column and results omitting forecasts in the right-hand column.

Chart A33: Bank lending, baseline

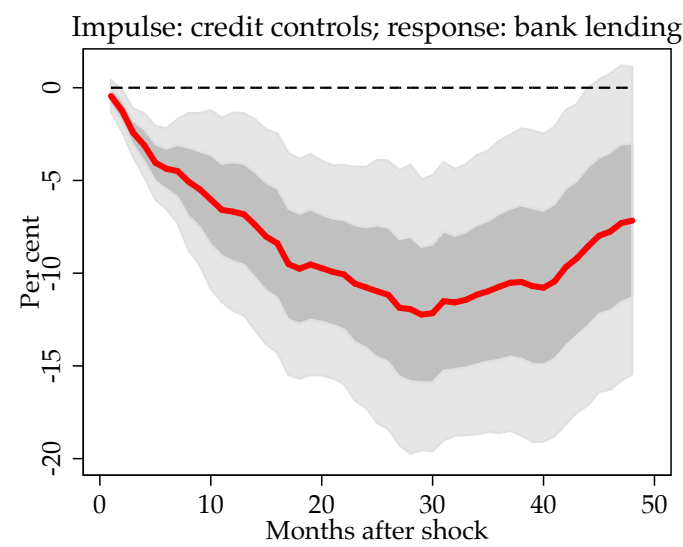

Chart A35: Manufacturing output, baseline

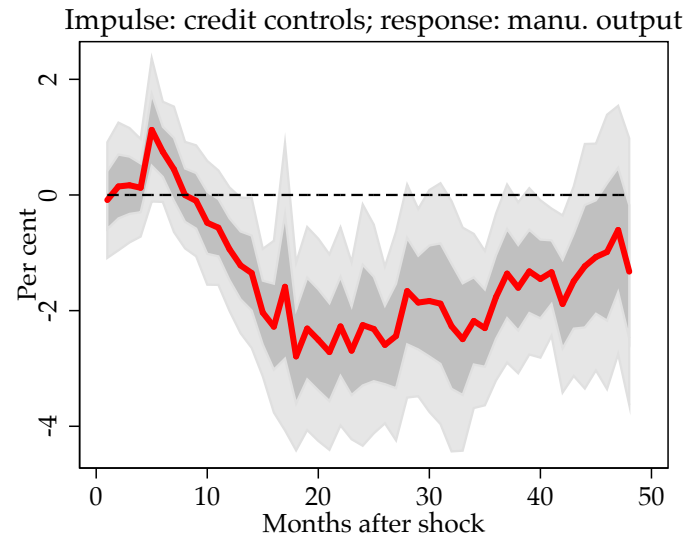

Chart A34: Bank lending, factor-only

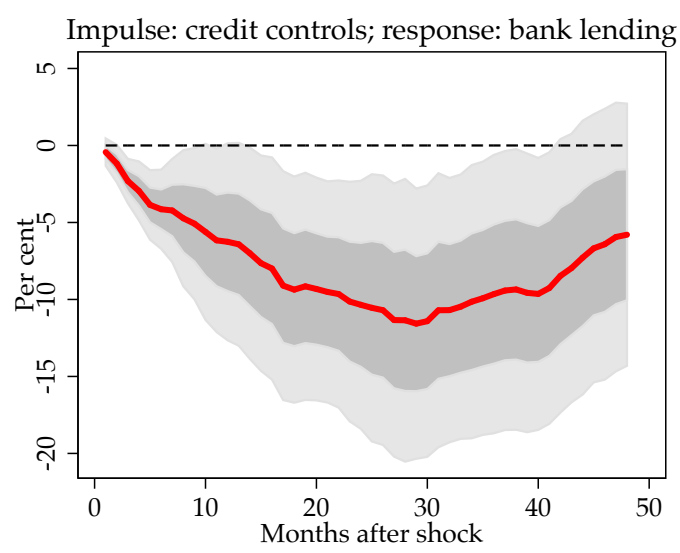

Chart A36: Manufacturing output, factoronly

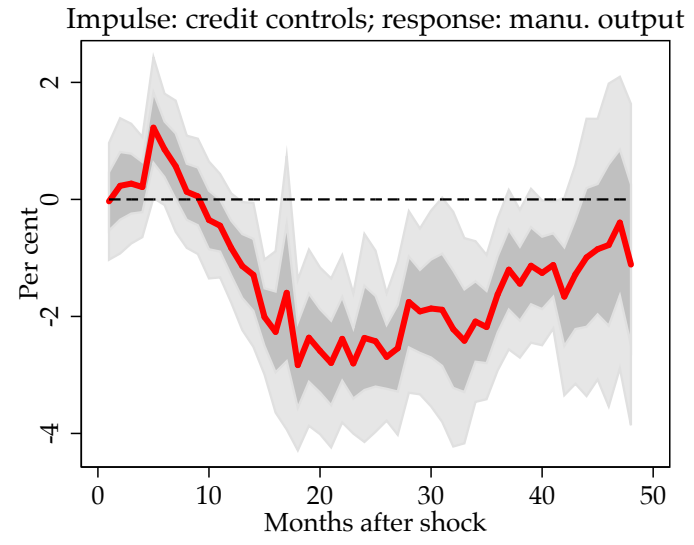


Chart A37: Consumer prices, baseline

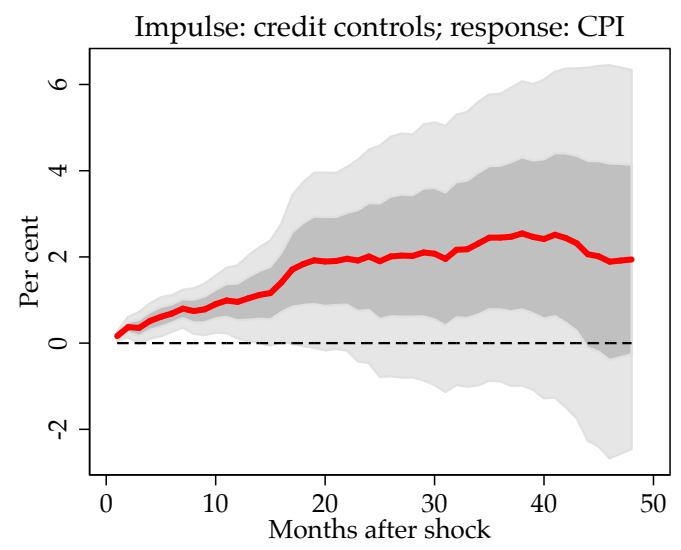

Chart A39: Trade balance, baseline

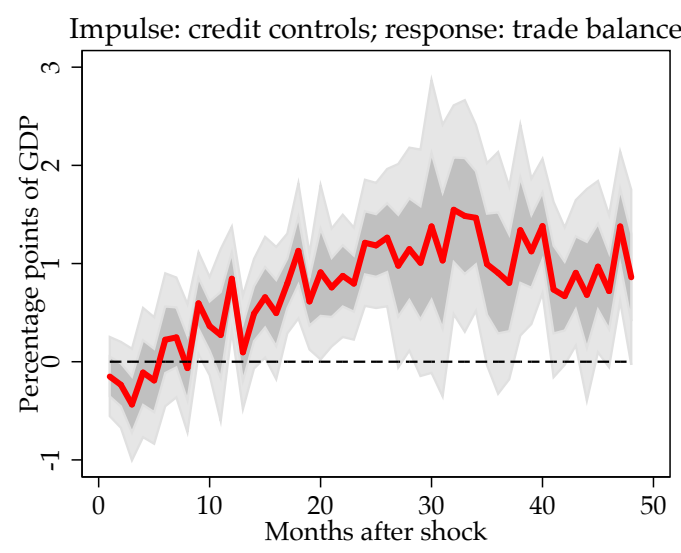

Chart A38: Consumer prices, factor-only

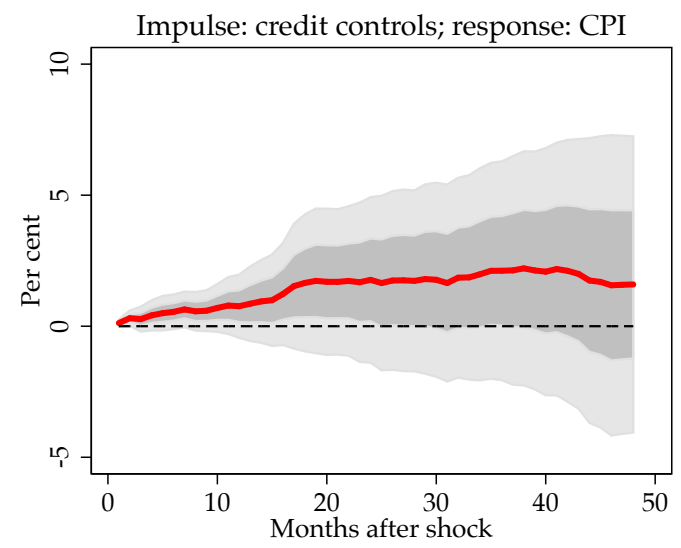

Chart A40: Trade balance, factor-only

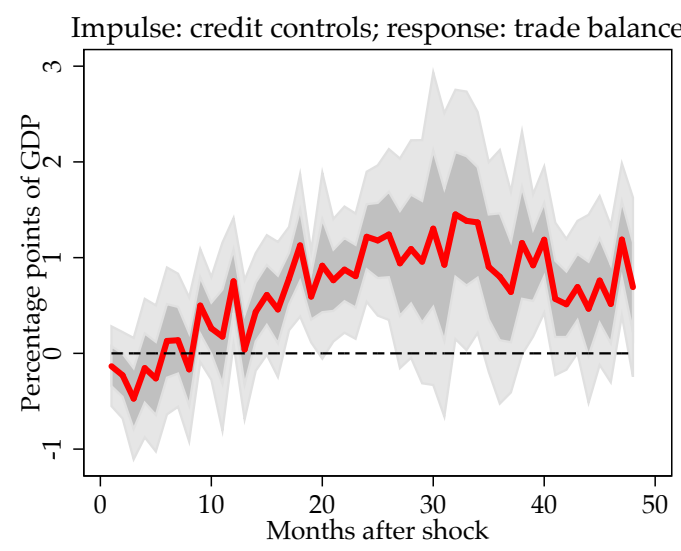




\section{Exhibit A7: Comparison with forecast-only approach: Bank Rate}

These panels compare results estimated using forecasts and factors in the left-hand column and results omitting factors in the right-hand column. Both columns' IRFs are estimated using a truncated sample, so as not to include months with out-of-date forecasts.

Chart A41: Bank lending, forecasts and Chart A42: Bank lending, forecast-only factors
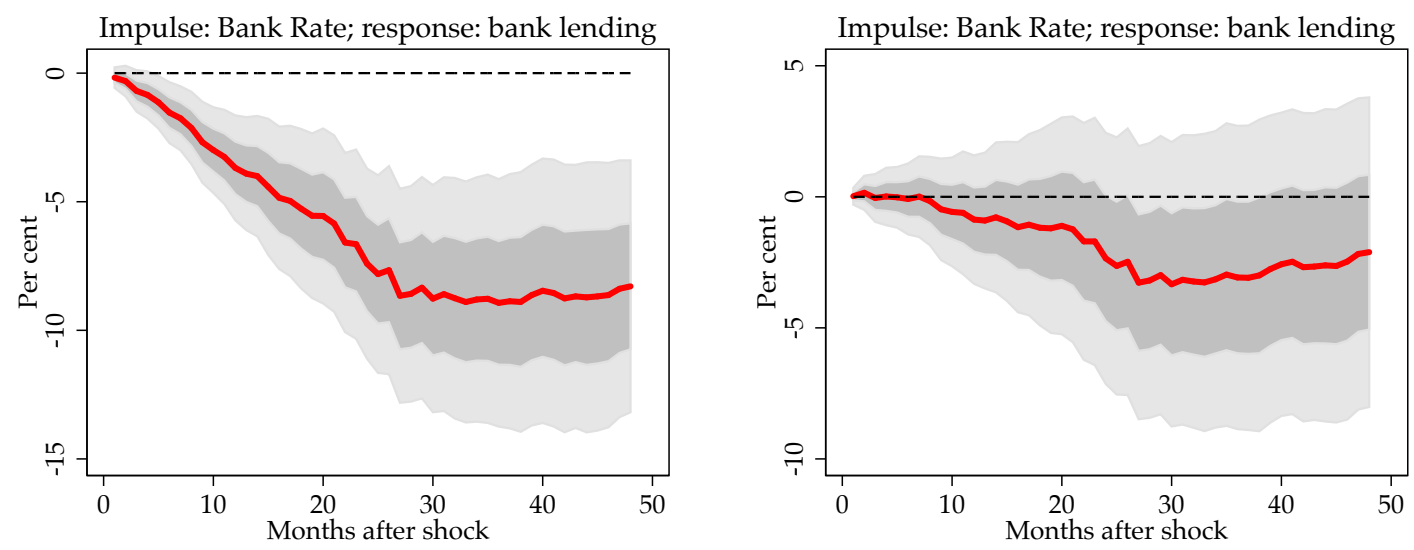

Chart A43: Manufacturing output, forecasts and factors

Chart A44: Manufacturing output, forecast-only
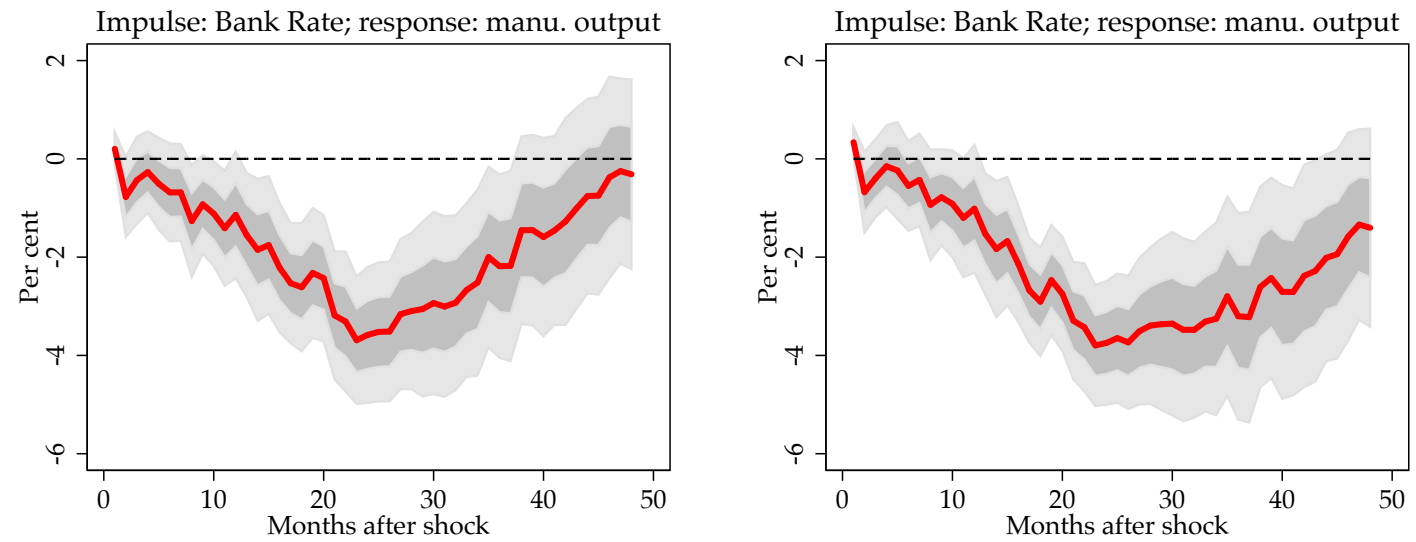
Chart A45: Consumer prices, forecasts and factors

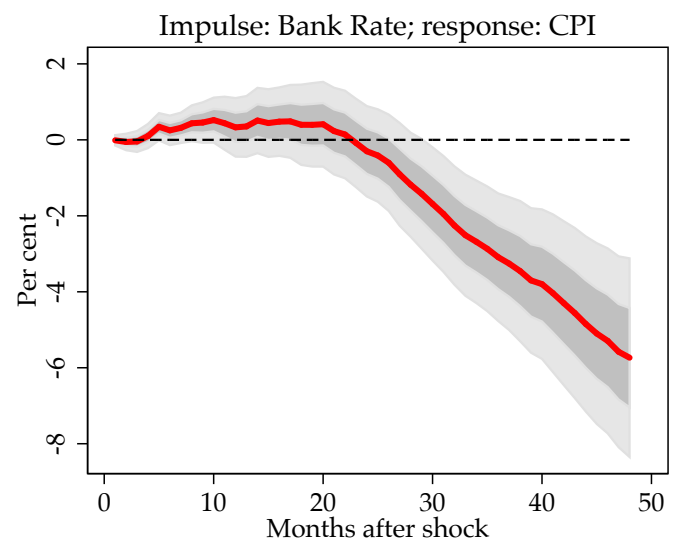

Chart A47: Trade balance, forecasts and factors

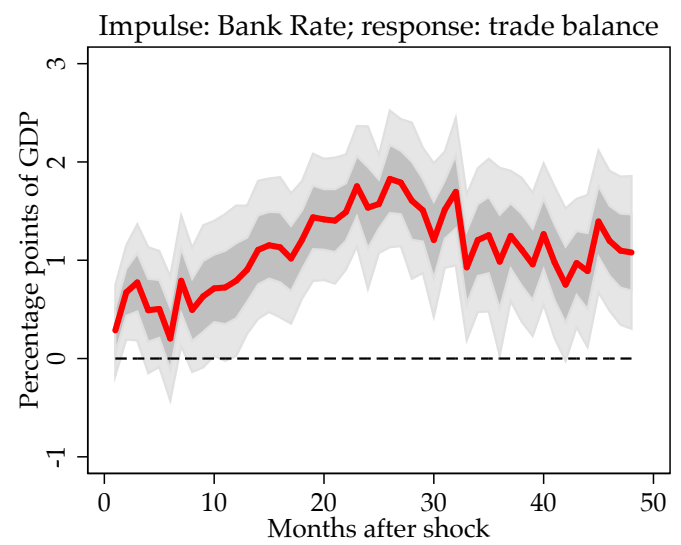

Chart A46: Consumer prices, forecastonly

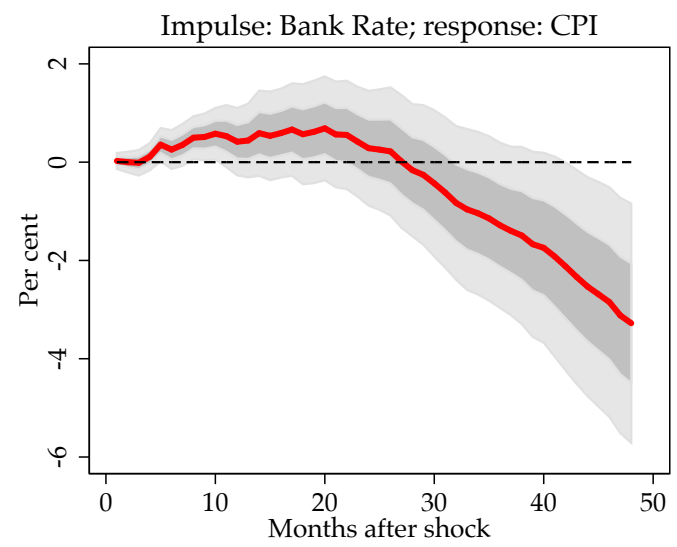

Chart A48: Trade balance, forecast-only

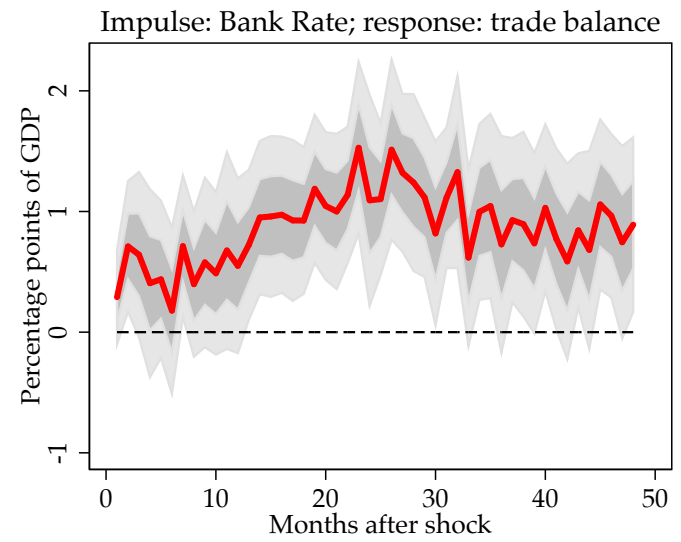




\section{Exhibit A8: Comparison with forecast-only approach: Credit controls}

These panels compare results estimated using forecasts and factors in the left-hand column and results omitting factors in the right-hand column. Both columns' IRFs are estimated using a truncated sample, so as not to include months with out-of-date forecasts.

Chart A49: Bank lending, forecasts and Chart A50: Bank lending, forecast-only factors
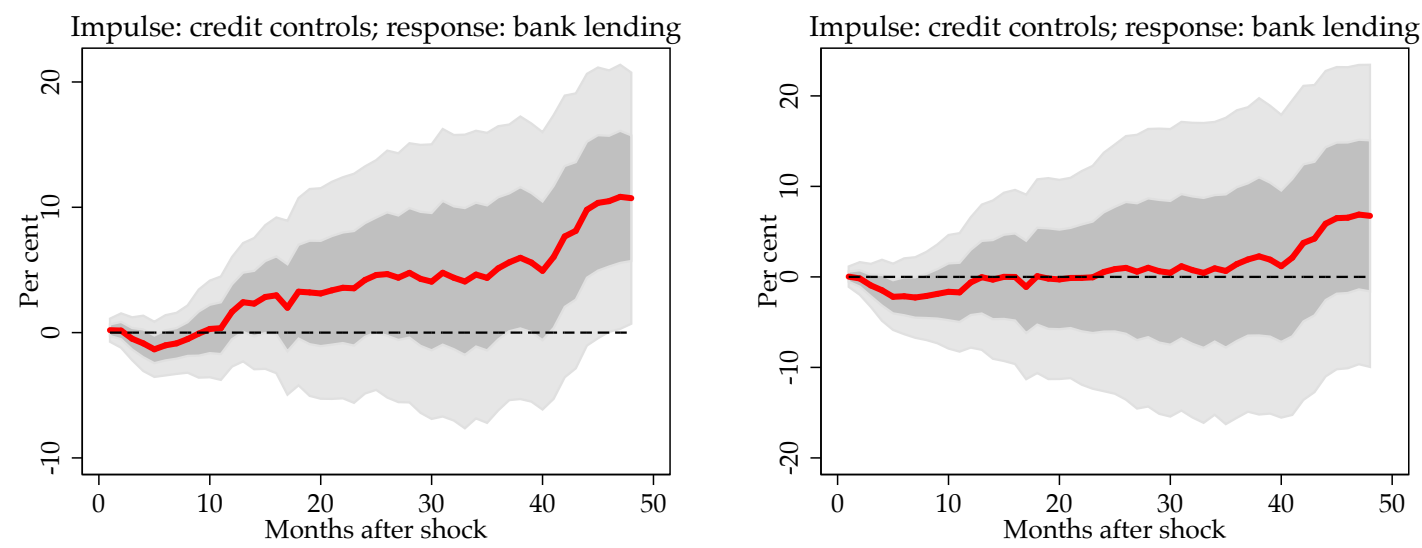

Chart A51: Manufacturing output, forecasts and factors

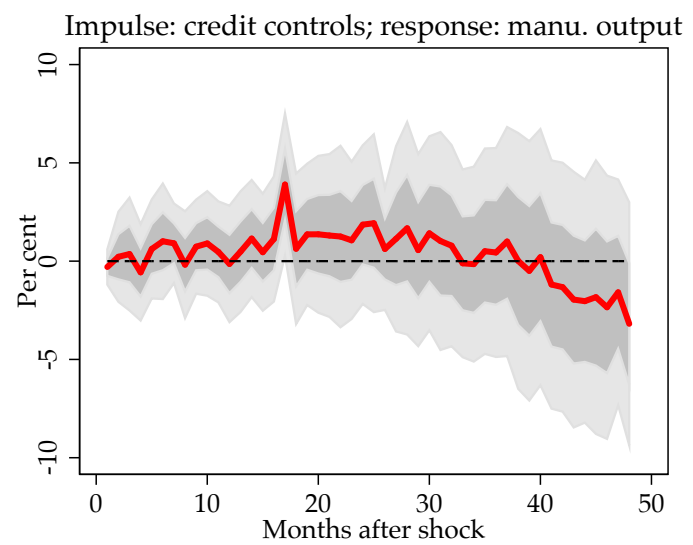

Chart A52: Manufacturing output, forecast-only

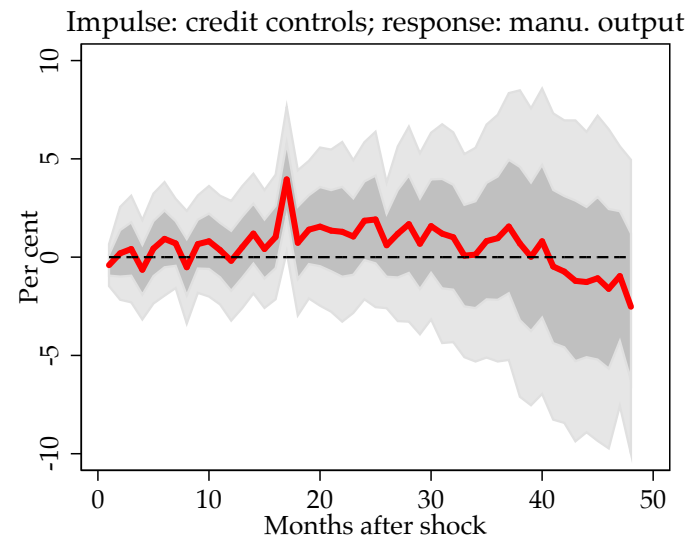


Chart A53: Consumer prices, forecasts and factors

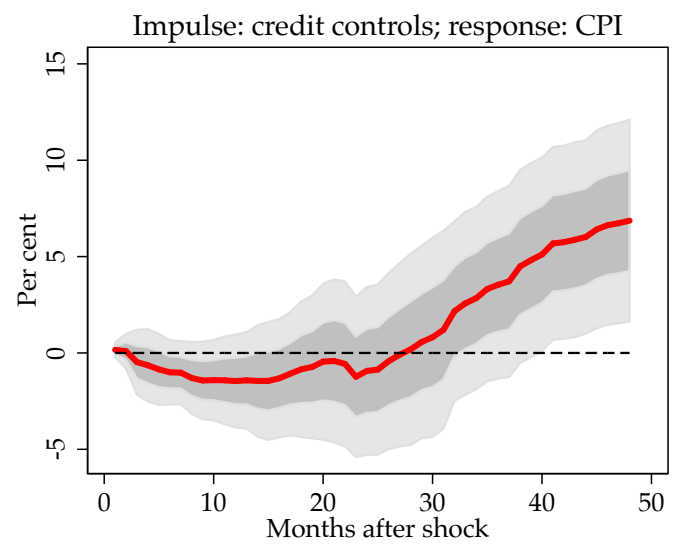

Chart A55: Trade balance, forecasts and factors

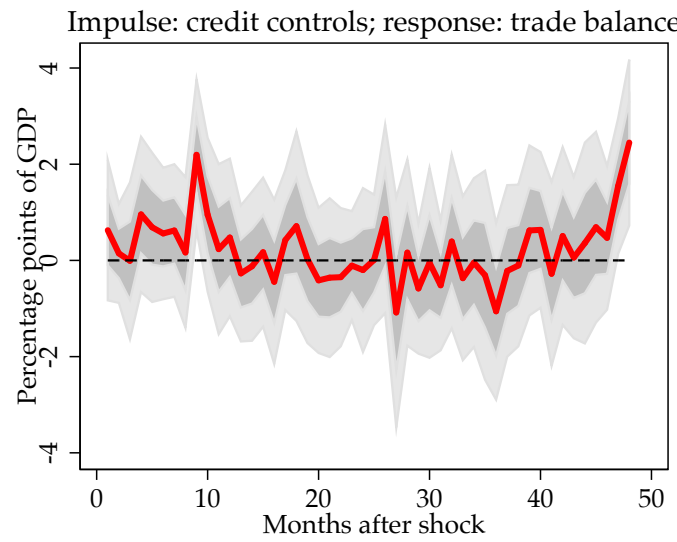

Chart A54: Consumer prices, forecastonly

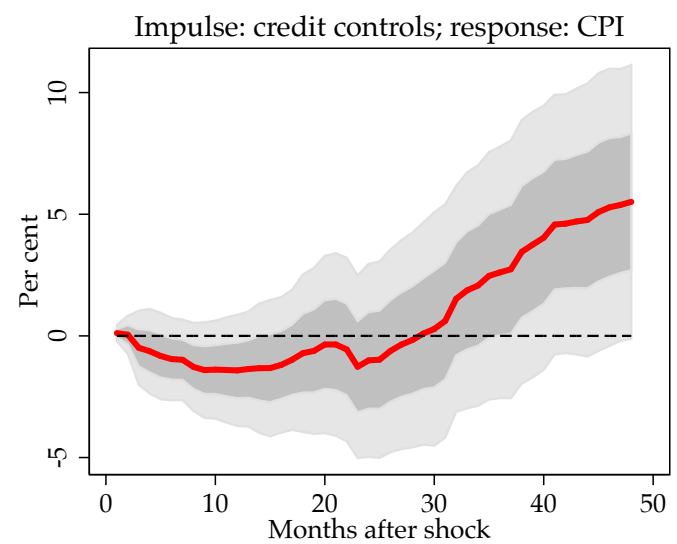

Chart A56: Trade balance, forecast-only

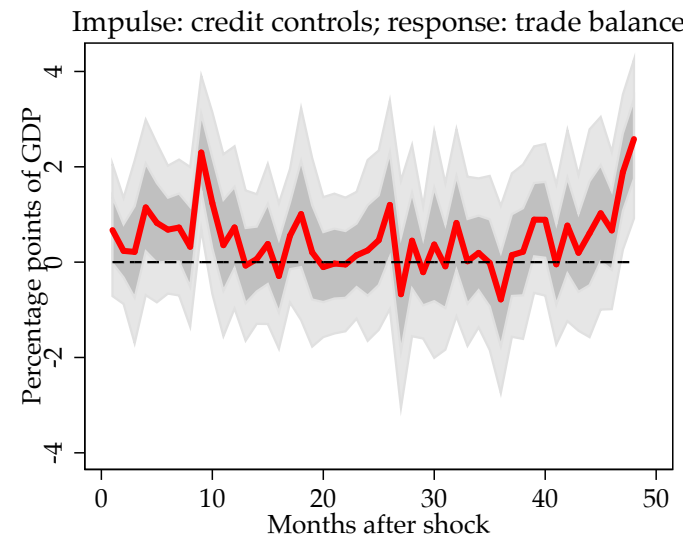

